\title{
EFFECT OF SOME DIFFERENT SOURCES AND RATES OF ORGANIC MANURE ON SUMMER SQUASH YIELD PRODUCTION
}

\author{
El- Afifi, S. T.; E. A. A. Tartoura and Sally M. Shaaban \\ Vegetables and Ornamentals Dept., Fac. Agric., Mans. Univ., Egypt. \\ E-mail: sayedtartoura@yahoo.com
}

\section{ABSTRACT}

This study was conducted during the two summer seasons of 2007 and 2008 at Abou Awad Village, Aga, Dakahila Governorate, Egypt, on summer squash Arlika F1 hybrid, to investigate the utilization of some different sources and rates of organic manures (mineral $\mathrm{N}$ fertilizer, rice straw compost, chicken and farmyard manure) at $200 \%$ and $100 \%$ of recommended rate/fed. from each source with foliar spraying of seaweed extracts (without and with $1 \mathrm{~g} / \mathrm{I}$ ) compared with mineral nitrogen fertilizer at $100 \%$ and $50 \%$ of recommended rate/ fed. and their interactions on plant growth, yield and quality as well as mineral NPK content.

A split-split plot design in complete randomized blocks with three replications in both seasons, seaweed extracts represented in the main plot which were sub divided to four sub plots were occupied with the treatments of organic nitrogen fertilizer sources while rates of organic nitrogen sources were assigned to the subsub plots.

The results indicated that most of plant growth parameters were significantly increased by foliar spraying with seaweed extracts of summer squash in both seasons. In addition, the treated squash plants with seaweed extracts produced more early yield, total yield and vitamin $C$ content and lower nitrate content in fruits. Moreover, an increase in NPK content in the leaves and fruits as compared with control were detected in the two growing seasons .

Application of compost manure (rice straw) gave the highest values of fresh and dry weight/plant, total yield and dry matter in both seasons. However the best early yield was obtained with chicken manure and FYM in the first and second seasons. While, lower nitrate content in the fruits was obtained with FYM and compost in the first and second season, respectively.

With increasing the rate of organic nitrogen fertilizer addition, all vegetative growth parameters, early yield, total yield and fruits quality as well as NPK in the leaves and fruits were significantly increased.

The interaction between seaweed extracts and organic nitrogen fertilizer sources and rates gave the highest values of vegetative characters, total yield in both seasons, but vitamin $C$ in fruits was increased in the first season when summer squash plants was fertilized with rice straw compost at $200 \%$ of recommended rate with spraying by seaweed extracts.

In general, it can be concluded that:

1- By conducting economical estimation, it appears that the maximum net return (4992 and 4854 L.E./fed.) were obtained with foliar spraying by seaweed extracts in combination with $200 \%$ of FYM, followed by rice straw compost at $200 \%$ of recommended rate/fed. respectively, comparing with control.

2- There are good opportunities to utilize and manipulate rice straw compost to enhance crop productivity and synonym essential to adopt a system of organic farming for obtained safe and clean food of vegetable crops against the chemical farming and also, reduce the risks of the environmental pollution.

3- Moreover, application organic manure affects of the chemical and physical properties of the soil as well as improve soil fertility. 
Keywords: Summer squash, organic farming, organic manure sources, rates, rice straw compost, farmyard manure, chicken manure, seaweed extracts, yield, nitrate content.

\section{INTRODUCTION}

Squash (Cucurbita pepo L.) is one of the most popular vegetable crops (Fam. Cucurbitaceae) in Egypt, because of high content of vitamin $\mathrm{A}_{1} \mathrm{~B}_{5}$ (niacin) and moderate content of vitamin $\mathrm{C}$ and riboflavin.

However, it is essential to adopt a system of organic farming in vegetables due to increasing the objectives against the chemical farming as a main source of soil and water pollution as well as food products.

Organic farming is a system that excludes the use of synthetic fertilizers, pesticides and growth regulators. Organic farmers rely heavily on crop rotations, crop residues, animal manures, legumes, green manures and organic wastes to feed the soil and supply nutrients. Insects, weeds and other pests are managed by mechanical cultivation, cultural and biological control (Codex, 2001).

Organic matter affects both the chemical and physical properties of the soil and its over all health. Properties influenced by organic matter include: soil structure, moisture holding capacity, diversity, activity of soil organisms and aggregate stability as well as minimize all forms of pollution which may result from agricultural practices ( Rechcigl,1995). Shehata (2001) reported that application of compost at rate $5 \mathrm{ton} /$ feddan which contained water hyacinth + peas + orange + chicken manure significantly increased vegetative growth characters and yield of squash. Nour (2004) indicated that application of $30 \mathrm{~m}^{3}$ chicken manure/fed were the best treatments in the both seasons for increasing pea yield and its components.

One of the biggest constraint in rice production in Delta area are how to deal with large quantities of rice residues in farm level. Actually, most of rice straw was burnt or removed after harvesting. These rice straw cannot be applied or ploughed directly into the soil because of their large C:N ratio. Ye et al. (1999) reported that application of rice straw + cattle manure at 40-60 $\mathrm{kg}$, significantly increased yield and fruit quality parameters. Luu Hong Man et al. (2001) The primary result in this long-term experiment could be concluded as following: 1. Application of rice straw manure increased yield over control $1.82 \%$ and $6.40 \% 2$. Rice straw manure combined with different doses of chemical fertilizer increased yield over control from $14.61-32.42 \%$ and $27.31-37.01 \%$ in wet season and in dry season, respectively. Rashid et al. (2001) compared mixtures of rice straw and nitrogen materials (cow dung + soybean plants) at ratios from 70 to $100 \%$ rice straw. The mixture containing $70 \%$ rice straw produced the most suitable compost in terms of maturity and nutrient status. Composting of rice straw with poultry manure and oilseed rape cake and its application at 20-200 g pot- 1 to faba bean plants improved selected soil chemical (increased total $N$ and CEC), physical (decreased particle density) and biological (increased soil respiration rate) properties and significantly increased yield and yield components of faba bean plants (Abdelhamid et al., 2004). El-Sherif (2006) obtained the highest early, total fruits yield, $\mathrm{N}$ and $\mathrm{K}$ in the leaves of cucumber plants grown in 
higher compost addition level at $6 \mathrm{t} / \mathrm{fed}$. compared with 2 and $4 \mathrm{t} / \mathrm{fed}$. Kabeel and Hasanin (2006) found that the addition of compost at rate 15t/fed. gave significantly greater total yields of potatoes compared with other levels at 10 and $20 \mathrm{t} / \mathrm{fed}$. Lee (2006) reported that, the mixture containing 70 to $80 \%$ rice straw and 60 to $70 \%$ hardwood bark were produced the most suitable compost in terms of nutrients and maturity. Results of pot experiment clarified that, the effectiveness of application of composted rice straw with chicken manure gave the highest grain, straw yield of barley in calcareous soil (Hellal, 2007).

Seaweed extracts as biological fertilizers contain appreciable quantities naturally of nutrients, hormones, amino acids and vitamins (Kusima, 1989 and Crouch and Van Standen, 1991). Nelson and Van Staden (1984) indicated that weekly sprayed with the seaweed extracts increased plant dry mass, root growth and leaf area of cucumber plants more than that unsprayed ones. El-Aidy et al. (2002) cleared that foliar application of pepper with seaweed extracts at dose $1 \mathrm{~g} / \mathrm{l}$ significantly increased fruits quality and mineral content (NPK). Bayoumi (2005) found that seaweed extracts at $1 \mathrm{~g} / \mathrm{l}$ gave a significantly increase in most vegetative growth characters of tomato plants.

This study was designed to determine the effect of organic nitrogen fertilizer sources and rates with foliar application of seaweed extracts on productivity of summer squash.

\section{MATERIALS AND METHODS}

This study was conducted during the two summer seasons of 2007 and 2008 at Abou Awad Village, Dakahila Governorate, Egypt, on summer squash Arlika F1 hybrid.

Some physical and chemical properties of the experimental soil at the depth of $0-30 \mathrm{~cm}$ shown in Table (1). Chemical analysis of the organic manures were cleared in Table (2). Chemical analyses of the organic manures were determined by using standard methods as described by A.O.A.C. (1990).

Two field experiments were conducted to evaluate seaweed extracts (control and $1 \mathrm{~g} / \mathrm{l}$ water) and three organic manures, i.e.:

Rice Straw Compost at $100 \%$ and $200 \%$ of recommended rate, chicken manure at $100 \%$ and $200 \%$ of recommended rate and farmyard manure (FYM) at $100 \%$ and $200 \%$ of recommended rate. Mineral nitrogen fertilizer at 30 and $60 \mathrm{~kg} / \mathrm{fed}$. was applied as control treatments.

A split-split plot design in complete randomized blocks with three replications in both seasons. Seaweed extracts represented in the main plot which were sub divided to four sub plots were occupied with the treatments of organic nitrogen fertilizer sources while rates of organic nitrogen sources were assigned to the sub- sub plots. The experiment included 16 treatments, each sub-sub plot was comprised of three ridges $5 \mathrm{~m}$ length, $1 \mathrm{~m}$ width and $50 \mathrm{~cm}$ spacing between plants in row, the sub- sub plot area was $15 \mathrm{~m}^{2}$.

Mineral fertilizer as a ammonium nitrate $(33.5 \% \mathrm{~N})$ was added in two equal portions after 2 and 4 weeks from seed sowing date. Calcium super phosphate $\left(15.5 \% \mathrm{P}_{2} \mathrm{O}_{5}\right)$ was applied once during soil preparation at the rate 
of $30 \mathrm{~kg} \mathrm{P} \mathrm{O}_{5} / \mathrm{feddan}$. Potassium sulphate $\left(48 \% \mathrm{~K}_{2} \mathrm{O}\right)$ at the rate of $48 \mathrm{~kg}$ $\mathrm{K}_{2} \mathrm{O} / \mathrm{fed}$. was applied twice, one half portion during soil preparation and the second half portion with the first rate of mineral nitrogen fertilizer.

Table (1): Some physical and chemical properties of the experimental soil during 2007 and 2008.

\begin{tabular}{|c|c|c|c|c|c|c|c|c|c|c|c|c|c|}
\hline \multirow{2}{*}{ Properties Sand\% } & $\begin{array}{c}\text { Silt } \\
\text { \% }\end{array}$ & Clay\% & Texture & O.M.\% & $\mathbf{C a C O}_{3}$ & \multirow{2}{*}{$\mathbf{p H}$} & \multicolumn{4}{|c|}{ Available nutrients (ppm) } \\
\cline { 8 - 12 } & & & & & & & $\mathbf{N}$ & $\mathbf{P}$ & $\mathbf{K}$ & $\mathbf{F e}$ & $\mathbf{Z n}$ & $\mathbf{M n}$ \\
\hline $\mathbf{2 0 0 7}$ & 23.36 & 17.44 & 56.18 & Clayey & 1.45 & 1.74 & 7.9 & 72.1 & 14.6 & 68.4 & 3.0 & 1.5 & 1.4 \\
\hline $\mathbf{2 0 0 8}$ & 26.25 & 17.90 & 55.85 & Clayey & 1.79 & 1.76 & 8.1 & 76.2 & 16.0 & 78.2 & 3.6 & 1.6 & 1.7 \\
\hline
\end{tabular}

Table (2): Chemical analysis and rates of the organic manures during 2007 and 2008 seasons.

\begin{tabular}{|c|c|c|c|c|c|c|}
\hline \multirow{2}{*}{$\begin{array}{l}\text { Source organic } \\
\text { Manures characters }\end{array}$} & \multicolumn{2}{|c|}{$\begin{array}{c}\text { Rice Straw } \\
\text { Compost }\end{array}$} & \multicolumn{2}{|c|}{$\begin{array}{c}\text { Chicken manure } \\
\text { with litter }\end{array}$} & \multicolumn{2}{|c|}{$\begin{array}{l}\text { Farmyard manure } \\
\text { without litter (FYM) }\end{array}$} \\
\hline & 2007 & 2008 & 2007 & 2008 & 2007 & 2008 \\
\hline $\mathrm{pH}$ & 7.2 & 7.0 & 8.0 & 8.2 & 7.2 & 7.0 \\
\hline $\mathrm{EC} \mathrm{dS} / \mathrm{m}$ & 4.8 & 5.1 & 6.3 & 6.0 & 4.0 & 4.2 \\
\hline $\mathrm{C}: \mathrm{N}$ ratio \% & 17.1: 1 & 17.2: 1 & 21.6: 1 & 21.3: 1 & 19.8: 1 & 21.5: 1 \\
\hline Humus value & 23.10 & 22.00 & - & - & - & - \\
\hline \multicolumn{7}{|l|}{ Macro-elements } \\
\hline Total nitrogen \% & 1.38 & 1.43 & 1.18 & 1.15 & 1.21 & 1.16 \\
\hline Total phosphorus \% & 0.55 & 0.60 & 0.72 & 0.79 & 0.55 & 0.60 \\
\hline Total potassium \% & 1.20 & 1.12 & 1.11 & 1.20 & 0.74 & 0.79 \\
\hline \multicolumn{7}{|l|}{ Micro-elements } \\
\hline Ferrous ppm & 930 & 875 & 425 & 369 & 545 & 610 \\
\hline Manganese ppm & 149 & 165 & 192 & 186 & 116 & 112 \\
\hline Copper ppm & 50 & 58 & 39 & 42 & 30 & 35 \\
\hline \begin{tabular}{|l|l} 
Zinc ppm & \\
\end{tabular} & 162 & 175 & 215 & 208 & 162 & 174 \\
\hline \multicolumn{7}{|c|}{ Organic manures rates of recommended rate $(\mathrm{t} / \mathrm{fed})$} \\
\hline \begin{tabular}{|l|l}
$100 \%$ & \\
\end{tabular} & 4.400 & 4.250 & 5.150 & 5.280 & 5.000 & 5.250 \\
\hline $200 \%$ & 8.800 & 8.500 & 10.300 & 10.560 & 10.000 & 10.500 \\
\hline
\end{tabular}

Organic fertilizer sources, crop nitrogen requirement needed for the desirable yield and the amount of nitrogen needed from organic manures was determined according nitrogen percentage input (chemical analysis for total nitrogen) from each source of organic manure to provide $60 \mathrm{~kg} \mathrm{~N} / \mathrm{fed}$. equivalent to traditional $\mathrm{N}$ fertilizer treatment. Organic manures were spread and thoroughly mixed with the surface of the soil layer $(0-30 \mathrm{~cm})$ before seed sowing during the soil preparation.

Seaweed extracts was used as foliar spraying at three times at two, four and six weeks after seed sowing date. Seaweed extracts (Algifert) were prepared as powder from of Ascophyllum nodosum and a biological fertilizer contains appreciable quantities of nutrients, phytohormones, amino acids and vitamins as shown in Table (3). It was obtained from Sidasa Egypt Company.

Compost manure prepared by mixing from plant materials of rice straw with fresh cattle manure and obtained from El-Kader Company in Zagazig City. Seeds squash Arlika $F_{1}$ hybrid was obtained from Syngenta Agro, S.A.E., Dokki, Giza, Egypt.

Seeds were sown on $20^{\text {th }}$ and $23^{\text {rd }}$ March in the first season and second season, respectively and harvested at 40 days from sowing date in the two seasons. Other agricultural practices were applied according to the 
organic farming recommendations.

\section{Data recorded}

\subsection{Vegetative growth characteristics}

A random sample of five plants were taken from each plot at 55 days after sowing in the both seasons, for measuring the growth parameters of summer squash plants expressed as follows:

- Number of leaves/plant

- Fresh weight/plant

- Dry weight/plant

- Leaf area/plant: it was determined

as described by Koller (1972) as follows:

Leaf area $\left(\mathrm{cm}^{2}\right)=$

dry weight of leaves $X$ number of disks $X$ disk area

dry weight of disks

- Total chlorophyll $(a+b)$ : the recently expanded leaves were determined colorimetrically as described in A.O.A.C. (1990).

Table (3): Analysis of seaweed extracts (Algifert)*.

\begin{tabular}{|c|c|c|c|}
\hline \multicolumn{2}{|l|}{ Macro elements (\%) } & \multicolumn{2}{|c|}{ Micro elements (ppm) } \\
\hline $\begin{array}{l}\text { Total nitrogen }(\mathrm{N}) \\
\text { Available }\left(\mathrm{P}_{2} \mathrm{O}_{5}\right) \\
\text { Soluble potash }\left(\mathrm{K}_{2} \mathrm{O}\right) \\
\text { Sulphur }(\mathrm{S}) \\
\text { Magnesium }(\mathrm{Mg}) \\
\text { Calcium }(\mathrm{Ca})\end{array}$ & $\begin{array}{c}1.0 \\
3.0 \\
18.0 \\
1.5 \\
0.3 \\
0.1\end{array}$ & $\begin{array}{l}\text { Boron }(\mathrm{B}) \\
\text { Iron }(\mathrm{Fe}) \\
\text { Manganese }(\mathrm{Mn}) \\
\text { Copper }(\mathrm{Cu}) \\
\text { Zinc }(\mathrm{Zn})\end{array}$ & $\begin{array}{c}110.0 \\
150.0 \\
10.0 \\
4.0 \\
50.0\end{array}$ \\
\hline \multicolumn{4}{|c|}{ Amino acids (average $\mathrm{g}$ of amino-acid/100 $\mathrm{g}$ of protein): } \\
\hline $\begin{array}{l}\text { Alanine } \\
\text { Arginine } \\
\text { Aspartic acid } \\
\text { Glutamic acid } \\
\text { Glycine } \\
\text { Histidine } \\
\text { Isoleucine } \\
\text { Leucine }\end{array}$ & $\begin{array}{l}3.81 \\
\\
0.22 \\
5.44 \\
7.69 \\
3.16 \\
0.42 \\
1.94 \\
\\
4.84 \\
\end{array}$ & $\begin{array}{l}\text { Lysine } \\
\text { Methionine } \\
\text { Phenylalinine } \\
\text { Proline } \\
\text { Serine } \\
\text { Threonine } \\
\text { Trosine } \\
\text { Valine }\end{array}$ & $\begin{array}{l}1.33 \\
1.39 \\
2.82 \\
4.42 \\
0.14 \\
1.27 \\
1.80 \\
3.46\end{array}$ \\
\hline \multicolumn{4}{|l|}{ Vitamins (ppm): } \\
\hline $\begin{array}{l}\text { Provit. A } \\
B_{1} \\
B_{2} \\
B_{12}\end{array}$ & $\begin{array}{c}40.0 \\
6.8 \\
6.0 \\
0.04\end{array}$ & $\begin{array}{l}\text { C } \\
D \\
\text { E } \\
\text { Niacin }\end{array}$ & $\begin{array}{c}300.0 \\
4.0 \\
70.0 \\
70.0\end{array}$ \\
\hline
\end{tabular}

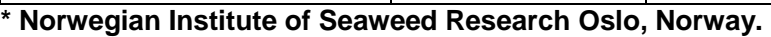

\section{Yield and fruits quality}

2.1. Early yield: the first six harvests were considered the early yield, it calculated as weight of fruits/plot $\left(15 \mathrm{~m}^{2}\right)$ then converted to $(\mathrm{kg} / \mathrm{fed})$.

2.2. Total yield the fruits were harvested day after day intervals up to the end of the harvest time (23 time harvest), it was measured as total weight of fruits/plots, then calculated total yield (ton/fed).

2.3. Fruit quality: it was determined at mid harvesting season, using representative samples, and was expressed as:

- Dry matter percentage, which determined in 100 grams of fresh fruit from 
the different samples of each treatment after oven drying at $70{ }^{\circ} \mathrm{C}$ until constant weight,

- Total soluble solids percentage (TSS\%) determined by hand Refractometer in extract of fruits.

- Vitamin C (ascorbic acid): it was estimated in samples by titration with 2, 6 dichlorophenol indophenal blue dye (Jacobs, 1951) and nitrate content in fruits (ppm) was measured according to the method described by Singh (1988).

\section{Chemical constituents}

The contents of $\mathrm{N}, \mathrm{P}$ and $\mathrm{K}$ were determined in the five leaves from the plant top at 45 days after seed sowing and NPK in fruits at mid harvesting time. Total nitrogen, phosphorus and potassium were determined according to the methods described by Bremner and Mulvaney (1982), Olsen and Sommers (19982) and Jackson (1970), respectively. Fe, Mn, and Zn were determined as described in Page et al. (1982) using an atomic absorption spectrophotometer. EC was determined according to Richards (1954). The other determinations were determined as described in Piper (1947), Black (1965 and Page et al. (1982)

4. Economic estimation:

Based on yield as an average of two seasons, addition net return was estimated.

\section{Statistical analysis}

All obtained data were subjected to statistical analysis as a split-split plot design in a randomized complete block design with three replicates in both seasons. All data were statistically analyzed according to the procedure outlined by Snedecor and Cochran (1967) the treatment means were compared using LSD of according Gomez and Gomez (1984).

\section{RESULTS AND DISCUSSION}

\section{Vegetative growth characters:}

\subsection{Effect of seaweed extracts}

Data presented in Table (4) show that the vegetative growth characters of summer squash, i.e., number of leaves/plant, leaf area/plant, fresh and dry weight/plant, total chlorophyll were significantly increased by foliar spray with seaweed extracts in both seasons. These results might be attributed to the beneficial effect of seaweed extracts owing to containing nutrients elements, plant growth hormones i.e. gibberellins, auxins and cytokinins (Kusima 1989) as well as other plant biostimulants (e.g. amino acids and vitamins which can maintain photosynthetic rates (Table 3). Moreover, increased plant resistances, delaying leaf senescence and controlling cell division could be participated in this respect (Nelson and Van Standen, 1984; Croush and Van Satnden, 1991; Van Staden et al., 1994; El-Saei and Tartoura, 2004; Awad, 2007; Tartoura and El-Saei 2005 and 2007).

\subsection{Effect of organic nitrogen fertilizer sources}

Data in same Table indicate that vegetative growth parameters of summer squash, were significantly affected by different organic nitrogen fertilizer sources in the two seasons. The highest significantly values of all 
vegetative growth parameters by treatment receiving compost manure followed by nitrogen fertilizer as an inorganic source in both seasons. Positive effect on growth characters by using compost manure this might be related to the improvement of physical conditions of the soil and supplying plant with mineral nutrients, i.e., NPK and micronutrients ( $\mathrm{Fe}, \mathrm{Zn}$ and $\mathrm{Mn}$ ), organic matter percentage as well as humic acid content (Table 2). Comparison with the other types of organic manure ( Alvarez et al. 1995; Kumaran, et al.1998 and Shehata, 2001 and Kabeel and Hasanin, 2006). Moreover, the superiority of plant growth characters results may be due to availability and rapid uptake of essential nutrients from mineral fertilizers (NPK) which in turn are the simulative effect of nitrogen in initiating the meristematic activity and enhancing the amount of metabolites necessary with building plant organs consequently improvement the vegetative growth of plants (Marschner, 1995). These results are in agreement with those obtained by El-Lithy et al. (1992), Hamail et al. (1994), El-Shabrawy (1997) and Ibrahim and Selim (2007) on summer squash plant.

\subsection{Effect of organic nitrogen fertilizer rates}

Also, data in Table (4) indicated clearly that the all vegetative growth characters of summer squash, were significantly increased by addition organic nitrogen fertilizer rates in both seasons. The application at $200 \%$ of recommended rate/fed. was superior values in all vegetative growth characters comparison with $100 \%$ of recommended rate in the two seasons. It could concluded that, the vigor plant growth characters of summer squash was associated with that plants which received the highest organic nitrogen at rate $200 \%$ of recommended. Its known that, The greatest amount fertilizer addition to the soil, the soluble and available nutrient elements increase in rooting zone of plant, improve soil physical, chemical properties and maintaining soil fertility, consequently their absorption increase. Also, it is worth to mention that, good effect of organic nitrogen treatment due to increasing plant growth parameters. These results are in accordance with those reported by El-Sherif (2006) on cucumber, Shaheen et al. (2007) on onion, Saleh et al. (2007) on tamato, Hossein (2008) on broccoli and ElKafrawy and Radwan (2008) on cucumber.

\subsection{Effect of the interaction between seaweed extracts and organic nitrogen fertilizer sources}

The interaction between seaweed extracts and organic nitrogen fertilizer sources had a positive significant effects on most vegetative growth characters of summer squash is presented in (Table 5) in both seasons. Data indicated that the plants treated with seaweed extracts and rice straw compost manure gave the highest values of all vegetative growth parameters in both seasons. On the other hand, the lowest values of vegetative growth parameters were recorded when the plants received chicken manure without foliar spraying with seaweed extracts in the two seasons. These results are in accordance with those reported by Bayoumi (2005) and Tartoura and EI-Saei (2007).

1.5. Effect of the interaction between seaweed extracts and organic nitrogen fertilizer rates

The interaction of seaweed extracts with organic nitrogen fertilizer rates 
resulted in a non-significant increase in vegetative growth of summer squash plants, expressed as number of leaves, leaf area in the two seasons, Table (5). However, this interaction was significantly affected on dry weight/ plant and total chlorophyll in second seasons. The interaction of seaweed extracts combination with $200 \%$ of recommended rate resulted in the highest values of all vegetative growth characters, compared with the interaction at $100 \%$ of recommended rate in both seasons. These increase might be due to their essential roles seaweed extracts contain naturally occurring supplying nutrients (Table 3) and plant growth hormones contain (Kusima, 1989; Zhang et al., 2003), and to positive effects of manure rate to improves soil fertility, moisture holding capacity of soils, thus allowing increased availability of certain nutrients (Duxbury et al. 1989).

Table (5): Effect of the interactions (seaweed extracts $X$ organic nitrogen fertilizer sources), (seaweed extracts $X$ rates) and (organic nitrogen sources $X$ rates) on some vegetative growth parameters of summer squash plants during 2007 and 2008 seasons.

\begin{tabular}{|c|c|c|c|c|c|c|c|c|c|c|c|}
\hline \multirow{2}{*}{\multicolumn{2}{|c|}{ Treatments }} & \multicolumn{2}{|c|}{$\begin{array}{c}\text { No. } \\
\text { leaves/plant }\end{array}$} & \multicolumn{2}{|c|}{$\begin{array}{c}\text { Leaf } \\
\text { area/plant } \\
\left(\mathrm{cm}^{2}\right) \\
\end{array}$} & \multicolumn{2}{|c|}{$\begin{array}{c}\text { Fresh } \\
\text { weight/plant } \\
(\mathrm{g})\end{array}$} & \multicolumn{2}{|c|}{\begin{tabular}{|c|} 
Dry \\
weight/plant \\
(g)
\end{tabular}} & \multicolumn{2}{|c|}{\begin{tabular}{|c|} 
Total \\
chlorophyll \\
(mg/100g) \\
\end{tabular}} \\
\hline & & 2007 & 2008 & 2007 & 2008 & 2007 & 2008 & 2007 & 2008 & 2007 & 2008 \\
\hline \multicolumn{12}{|c|}{ Seaweed X Sources interaction } \\
\hline \multirow{4}{*}{ With } & Mineral & 26.66 & 26.78 & 3310.5 & 3365.3 & 822.38 & 784.72 & 79.93 & 80.42 & 121.87 & 148.88 \\
\hline & $\begin{array}{l}\text { Rice Straw } \\
\text { Compost }\end{array}$ & 24.50 & 24.98 & 3274.5 & 3309.7 & 858.38 & 863.62 & 89.47 & 91.90 & 142.23 & 143.25 \\
\hline & $\begin{array}{l}\text { Chicken } \\
\text { Manure }\end{array}$ & 24.05 & 24.55 & 3097.1 & 3154.2 & $\mid 781.36$ & 716.87 & 67.30 & 78.90 & 138.38 & 151.43 \\
\hline & FYM & 23.98 & 23.84 & 3155.3 & 3264.2 & 778.67 & 766.38 & 79.60 & 81.30 & 131.88 & 134.86 \\
\hline \multirow{4}{*}{ Without } & Mineral & 25.71 & & 3084.1 & 3144.0 & 739.72 & 769.61 & 72.62 & 73.88 & 113.20 & 140.71 \\
\hline & $\begin{array}{l}\text { Rice Straw } \\
\text { Compost }\end{array}$ & 24.17 & 23.75 & 3022.0 & 3053.5 & 817.16 & 811.30 & 84.80 & 84.07 & 130.15 & 141.51 \\
\hline & $\begin{array}{l}\text { Chicken } \\
\text { Manure }\end{array}$ & 23.80 & 23.68 & 2884.8 & 2901.7 & 632.16 & 654.10 & 71.50 & 71.82 & 127.53 & 134.06 \\
\hline & FYM & 23.95 & 24.26 & 2951.5 & 2970.0 & 730.98 & 709.58 & 75.90 & 76.80 & 123.97 & 114.37 \\
\hline LSD at 5 & & 0.85 & \begin{tabular}{|l|}
0.86 \\
\end{tabular} & 35.80 & 30.20 & \begin{tabular}{|l|}
20.75 \\
\end{tabular} & 106.20 & 11.71 & 3.32 & \begin{tabular}{|l|}
3.60 \\
\end{tabular} & 5.99 \\
\hline \multicolumn{12}{|c|}{ Seaweed X Rates interaction } \\
\hline \multirow{2}{*}{ With } & $100 \%$ & 24.12 & 24.05 & 2825.7 & 863.4 & 977.52 & 617.60 & 64.85 & 70.31 & 121.0 & 132.43 \\
\hline & $200 \%$ & 25.48 & 26.02 & 3584.0 & 683.3 & 942.88 & 948.19 & 93.30 & 95.95 & 146.0 & 56.78 \\
\hline \multirow{2}{*}{ Without } & $100 \%$ & 23.89 & 23.73 & 2567.1 & 2616.0 & 613.46 & 618.43 & 65.96 & 66.63 & 111.36 & 127.63 \\
\hline & $200 \%$ & 24.93 & 25.06 & 3394.0 & 3419.0 & 846.56 & 853.87 & 86.45 & 86.65 & 136.07 & 137.69 \\
\hline LSD at 5 & & NS & NS & 54.58 & 32.12 & 12.86 & 69.86 & NS & 1.15 & NS & 8.54 \\
\hline \multicolumn{12}{|c|}{ Sources X Rates interaction } \\
\hline \multirow{2}{*}{ Mineral } & $50 \%$ & 25.40 & 25.11 & 2748.3 & 1704 & & & 61.80 & 61.27 & 110.07 & 135.96 \\
\hline & $100 \%$ & 26.98 & 27.56 & 3646.3 & | & & 1034.94 & 90.75 & 93.03 & & 153.63 \\
\hline \multirow{2}{*}{\begin{tabular}{|l|} 
Rice \\
Straw \\
Compost
\end{tabular}} & $100 \%$ & 23.78 & 23.46 & 2753.3 & 2757.8 & 736.63 & 736.46 & 74.43 & 75.62 & 121.53 & 131.02 \\
\hline & $00 \%$ & 24.88 & 25.27 & 3543.1 & 3605.3 & 938.92 & 838.46 & 99.83 & 100.35 & 150.8 & 153.74 \\
\hline \multirow{2}{*}{$\begin{array}{l}\text { Chicken } \\
\text { Manure }\end{array}$} & $100 \%$ & 23.43 & 23.71 & 2753.3 & 2648,2 & 601.16 & 585.66 & 56.95 & 67.98 & 116.47 & 133.93 \\
\hline & $200 \%$ & 24.42 & 24.53 & 3348.3 & 3407.7 & 812.36 & 785.31 & 81.85 & 82.73 & 149.45 & 151.56 \\
\hline \multirow{2}{*}{ FYM } & $100 \%$ & 23.39 & 23.28 & 2668.5 & 2758.2 & 646.31 & 630.56 & 68.43 & 69.02 & 116.83 & 119.21 \\
\hline & $200 \%$ & 24.53 & 24.82 & 3418.3 & 3476.0 & 863.33 & 845.39 & 87.07 & 89.08 & 139.02 & 130.02 \\
\hline \multicolumn{2}{|c|}{ LSD at $5 \%$} & NS & \begin{tabular}{|l|}
0.73 \\
\end{tabular} & 54.58 & 47.87 & \begin{tabular}{|l|}
18.18 \\
\end{tabular} & 98.80 & NS & 1.63 & 2.82 & NS \\
\hline
\end{tabular}




\subsection{Effect of the interaction between organic nitrogen fertilizer sources and rates}

Data in Table (5) illustrated that the interaction between organic nitrogen sources and rates had a significant effect on number of leaves, leaf area, fresh and dry weight/plant and total chlorophyll $a+b$ of summer squash in both seasons, except number of leaves and dry weight/plant in the first season and total chlorophyll in the second season. The highest values of most vegetative parameters were obtained by treatment receiving compost manure at $200 \%$ of recommended rate and/or $100 \%$ nitrogen of recommended rate/fed. as an inorganic source in both seasons. While, the lowest values with most vegetative parameters of summer squash were noticed when it received mineral nitrogen fertilizer at $50 \%$ of recommended rate without seaweed extracts in the two seasons. These results are in agreement with those obtained by El-Shabrawy (1997) and Ibrahim and Selim (2007) on summer squash plant. They found that organic nitrogen fertilizer as a source of compost significantly increased of vegetative growth parameters (Abou- Hussein et al., 2002; El-Sherif, 2006).

\subsection{Effect of the interaction among seaweed extracts, organic nitrogen fertilizer sources and rates}

As for the interaction effect of the three studied factors, data in Table (6) reveal that vegetative growth characters influenced by the interaction in both seasons. Generally, plants of summer squash treated with seaweed extracts combination with rice straw compost at $200 \%$ of recommended and/or nitrogen mineral fertilizer at $100 \%$ of recommended rate produced the highest vegetative growth characters in the two seasons, whereas the lowest values were obtained as a result of untreated by seaweed extracts with mineral fertilizer at $50 \%$ followed by chicken manure at $100 \%$ of recommended rate in both seasons.

\section{Yield and fruit quality}

\subsection{Effect of seaweed extracts}

Data illustrated in Table (7) show that early yield and total yield were significantly increased with foliar application of seaweed extracts. The percentage of increment were estimated to be $10.95 \%$ and $11.20 \%$ in the first season and second season, respectively. The increases occurred in total fruit yield might be attributed to the increase in vegetative growth characteristics (Table 4 ) and reproductive phases of plants which have impact on total fruit yield. These results are in agreement with those obtained by Crouch and Van Staden (1992), Turemis et al. (1998).

Table (6): Effect of the interaction among seaweed extracts, organic nitrogen fertilizer sources and rates on some vegetative growth parameters of summer squash plants during 2007 and 2008 seasons.

\begin{tabular}{|c|c|c|c|c|c|c|c|c|c|c|c|c|}
\hline \multicolumn{3}{|c|}{ Characters } & \multicolumn{2}{|c|}{$\begin{array}{c}\text { No. } \\
\text { leaves/plant }\end{array}$} & \multicolumn{2}{|c|}{$\begin{array}{c}\text { Leaf } \\
\text { area/plant } \\
\left(\mathrm{cm}^{2}\right)\end{array}$} & \multicolumn{2}{|c|}{$\begin{array}{c}\text { Fresh } \\
\text { weight/plant } \\
\text { (g) }\end{array}$} & \multicolumn{2}{|c|}{$\begin{array}{c}\text { Dry } \\
\text { weight/plant } \\
\text { (g) }\end{array}$} & \multicolumn{2}{|c|}{$\begin{array}{c}\text { Total } \\
\text { chlorophyll } \\
\text { (mg/100g) }\end{array}$} \\
\hline & & & & 8 & 2007 & 2008 & 2007 & 2008 & 2007 & 2008 & 2007 & 2008 \\
\hline \multirow{3}{*}{ Vith } & & & & & 2845.6 & & .52 & & & & 112.77 & \\
\hline & & & & & & 3834.7 & 1023.23 & & & 98.33 & 130.97 & 162.42 \\
\hline & Rice & $100 \%$ & 23.70 & 24.07 & 2911.6 & 2901.7 & 753.53 & 753.44 & 75.50 & 77.60 & 123.87 & 129.18 \\
\hline
\end{tabular}




\begin{tabular}{|c|c|c|c|c|c|c|c|c|c|c|c|c|}
\hline & $\begin{array}{l}\text { Straw } \\
\text { Compost }\end{array}$ & $200 \%$ & 25.29 & 25.90 & 3637.3 & 3717.7 & 963.23 & 973.79 & 103.43 & 106.20 & 155.60 & 157.32 \\
\hline & Chicken & $100 \%$ & 23.53 & 24.18 & 2733.3 & 2751.3 & 669.13 & 619.77 & 50.43 & 71.83 & 122.57 & 140.16 \\
\hline & & 200 & 4.57 & 24.92 & 3425.0 & 3557.0 & 893.58 & 813.97 & 84.17 & 85.97 & 154.20 & 162.70 \\
\hline & & $100 \%$ & & 23.05 & & & & & & 69.30 & & 25.06 \\
\hline & FYIM & & 4.47 & 24.63 & & & & .85 & 90.63 & 93.30 & 3.60 & 144.83 \\
\hline \multirow{8}{*}{ Without } & \multirow{2}{*}{ Mineral } & & 5.05 & 25.30 & & & & .47 & .70 & .03 & .37 & \\
\hline & & 100 & 26.37 & 26.49 & 3517.3 & 3595.0 & 905.28 & 945.75 & 86.53 & \begin{tabular}{|l|}
87.73 \\
\end{tabular} & 9.03 & 144.83 \\
\hline & \multirow{2}{*}{\begin{tabular}{|l|} 
Rice \\
Straw \\
Compost \\
\end{tabular}} & $100 \%$ & 23.87 & 22.85 & 2595.0 & 2614.0 & 719.72 & 719.47 & 73.37 & 73.63 & 114.20 & 132.86 \\
\hline & & $200 \%$ & 24.47 & 24.64 & 3449.0 & 3493.0 & 914.61 & 903.13 & 96.23 & 94.50 & 146.10 & 150.15 \\
\hline & \multirow{2}{*}{\begin{tabular}{|l|} 
Chicken \\
Manure \\
\end{tabular}} & $100 \%$ & 23.33 & 23.23 & \begin{tabular}{|l|}
2498.0 \\
\end{tabular} & 2545.0 & 533.19 & 551.55 & 63.47 & 64.13 & 110.37 & 127.70 \\
\hline & & $200 \%$ & 24.27 & 24.13 & 3271.6 & 3258.0 & 731.13 & 756.65 & 79.53 & 79.50 & 144.70 & 140.42 \\
\hline & \multirow{2}{*}{ FYM } & $100 \%$ & 23.30 & 23.52 & 2524.6 & 2611.6 & 626.75 & 609.22 & 68.30 & 68.73 & 113.50 & 113.37 \\
\hline & & $200 \%$ & 24.60 & 25.00 & 3338.3 & 3328.3 & 835.20 & 809.93 & 83.50 & 84.87 & 134.43 & 115.37 \\
\hline \multicolumn{3}{|c|}{ LSD at $5 \%$} & NS & 1.04 & \begin{tabular}{|l|}
77.18 \\
\end{tabular} & 64.24 & NS & \begin{tabular}{|l|} 
NS \\
\end{tabular} & NS & 2.30 & 3.99 & NS \\
\hline
\end{tabular}

Table (7): Effect of seaweed extracts, organic nitrogen fertilizer sources and rates on yield and fruit quality parameters of summer squash plants during 2007 and 2008 seasons.

\begin{tabular}{|c|c|c|c|c|c|c|c|c|c|c|c|c|}
\hline Characters & $\begin{array}{c}\text { Early } \\
\text { (kg/f }\end{array}$ & $\begin{array}{l}\text { yield } \\
\text { fed.) }\end{array}$ & $\begin{array}{c}\text { Total } \\
\text { (ton// }\end{array}$ & $\begin{array}{l}\text { yield } \\
\text { fed.) }\end{array}$ & Dry n & $\begin{array}{l}\text { natter } \\
\text { \%) }\end{array}$ & & & $\begin{array}{r}\mathrm{V} \\
(\mathrm{mg} / \\
\mathrm{F} .\end{array}$ & $\begin{array}{l}\text { C } \\
100 \mathrm{~g} \\
W)\end{array}$ & & $\begin{array}{l}\mathrm{O}_{3} \\
\mathrm{~m})\end{array}$ \\
\hline Treat & 2007 & 2008 & 2007 & 2008 & 2007 & 2008 & 2007 & 2008 & 2007 & 2008 & 2007 & 2008 \\
\hline A- Seaweed extr & acts & & & & & & & & & & & \\
\hline With & 577.69 & 571.99 & 10.94 & 11.42 & 4.73 & 5.40 & 5.05 & 5.12 & 13.12 & 12.89 & 30.62 & 27.25 \\
\hline Without & 523.74 & 532.17 & 9.86 & 10.27 & 4.41 & 4.98 & 4.57 & 4.54 & 11.99 & 11.97 & 33.45 & 32.68 \\
\hline F Test & * & * & * & * & * & * & NS & NS & * & * & NS & * \\
\hline B-Sources: & & & & & & & & & & & & \\
\hline Mineral & 386.28 & 390.63 & 10.18 & 10.94 & 4.38 & 4.95 & 4.39 & 4.39 & 11.31 & 10.74 & 47.90 & 44.19 \\
\hline $\begin{array}{l}\text { Rice Straw } \\
\text { Compost }\end{array}$ & 516.23 & 560.37 & 10.82 & 11.23 & 5.06 & 5.79 & 4.73 & 4.74 & 14.57 & 12.52 & 26.65 & 20.73 \\
\hline Chicken Manure & 664.50 & 591.37 & 10.06 & 10.49 & 4.20 & 4.69 & 5.14 & 5.12 & 12.58 & 14.57 & 32.09 & 32.23 \\
\hline FYM & 635.87 & 665.95 & 10.54 & 10.87 & 4.64 & 5.32 & 4.98 & 5.07 & 11.75 & 11.89 & 21.50 & 22.71 \\
\hline LSD at $5 \%$ & 26.97 & 15.58 & 0.06 & 0.03 & 0.10 & 0.20 & 0.16 & 0.17 & 0.50 & 0.36 & 2.81 & 1.17 \\
\hline C-Rates: & & & & & & & & & & & & \\
\hline $100 \%$ & 495.79 & 484.57 & 8.16 & 9.06 & 4.09 & 4.80 & 4.39 & 4.48 & 11.80 & 11.74 & 28.08 & 26.69 \\
\hline $200 \%$ & 605.64 & 619.59 & 12.63 & 12.62 & 5.05 & 5.58 & 5.23 & 5.18 & 13.31 & 13.12 & 35.99 & 33.24 \\
\hline F Test & * & * & $*$ & * & * & * & * & * & * & * & * & * \\
\hline
\end{tabular}

Data in the same Table indicated that foliar spraying of seaweed extracts on summer squash had positive significant effect on dry matter percentage, vitamin $C$ and nitrate contents in fruits of squash in the two seasons. Results also, indicate that treated plants with seaweed extracts gave the highest values of dry matter percentage, vitamin $C$ and minimum nitrate content in the squash fruits compared with untreated plants in the two growing seasons, respectively. But, TSS \% was not significantly affected by addition of seaweed extracts in both seasons. Such increase in dry matter and vitamin C contents could be attributed to being seaweed extracts contained a lot of much amount of macro and micro elements, carbohydrates and growth hormones, vitamins and amino acids (Table 3 ), their compounds have one or more of important biological functions which referred to the stimulative role of plant growth consequently more dry matter and vitamin $\mathrm{C}$ contents (Eris et al., 1995; El-Aidy et al., 2002; Zodape, 2002). 


\subsection{Effect of organic nitrogen fertilizer sources}

Data illustrated in Table (7) show that total yield and fruit quality of summer squash, i.e., early yield, total, dry matter and TSS as well as nitrate content in fruits were significantly increased by various organic nitrogen fertilizer sources in the two seasons. The highest early yield was recorded with the plants were given chicken manure and FYM in the first season and second season as compared with different organic nitrogen fertilizer sources. Also, the maximum values of total fruits yield, dry matter and TSS were produced when plants received compost manure compared with other treatments of organic manures in the two growing seasons. While the lowest nitrate content was recorded with FYM and compost manure in the first and second season respectively. This increase in yield and fruits quality may be due to the increasing in vegetative growth parameters i.e., plant length, total chlorophyll, fresh and dry weight/plant, number of leaves/plant as well as leaf area/plant as shown in (Table 4). It may be also stated that the sufficient addition and the efficient absorption of nutrients were coupled together to promote the production of more photosynthesis required for good yield and fruits quality. The results are in harmony with those obtained by Seyedbagheri (1999), Aly (2002), Saleh et al. (2007), and El-Kafrawy and Radwan (2008).

\subsection{Effect of organic nitrogen fertilizer rates}

Data in the same Table also, indicated clearly effect of organic nitrogen fertilizer rates on yield and fruits quality of summer squash, increasing the supplied organic manure rates from $100 \%$ to $200 \%$ of recommended rate/fed. significantly increased early yield by $14.18 \%$ and $21.79 \%$, total yield $35.39 \%$ and $28.21 \%$ in both seasons, respectively. These increments might due to the role of organic nitrogen fertilizer in enhancing vegetative growth characters (Table 4), which increases the photosynthetic rates leading to an increase the net assimilation rates, consequently this will reflected on yield and its components. Similar results have been found by Shaheen et al. (2007) on onion, Hossein (2008) on broccoli, El-Kafrawy and Radwan (2008) on cucumber.

\subsection{Effect of the interaction between seaweed extracts and organic nitrogen fertilizer sources}

It is evident from Table (8) that interaction of seaweed extracts with organic nitrogen fertilizer sources affected total yield and TSS in both seasons, early yield and nitrate content in fruits of summer squash in the second season and vitamin $C$ in the first season. However, dry matter was not significantly influenced by interaction in the two seasons. It was clear that plants sprayed by seaweed extracts combined with compost manure followed by FYM gave the highest values of yield and its components in both seasons.

On the other hand, the lowest level of nitrate content in summer squash fruits was resulted from plants received FYM or compost manure and sprayed with seaweed extracts in the first season and second season, respectively. The obtained results are in agreement with those of Bayoumi (2005) and Bayoumi and Hafez (2006). 
Table (8): Effect of the interactions (seaweed extracts $X$ organic nitrogen fertilizer sources), (seaweed extracts $X$ rates) and (organic nitrogen sources $X$ rates) on yield and fruit quality parameters of summer squash plants during 2007 and 2008 seasons.

\begin{tabular}{|c|c|c|c|c|c|c|c|c|c|c|c|}
\hline \multirow{2}{*}{ Treatments } & $\begin{array}{c}\text { Early yield } \\
\text { (kg/fed.) }\end{array}$ & \multicolumn{2}{|c|}{$\begin{array}{c}\text { Total yield } \\
\text { (ton/fed.) }\end{array}$} & \multicolumn{2}{|c|}{$\underset{(\%)}{\text { Dry matter }}$} & \multicolumn{2}{|c|}{$\begin{array}{r}\text { TSS } \\
(\%)\end{array}$} & \multicolumn{2}{|c|}{$\begin{array}{c}\text { V.C } \\
(\mathrm{mg} / 100 \mathrm{~g} \\
\text { F.W) }\end{array}$} & \multicolumn{2}{|c|}{$\begin{array}{c}\mathrm{NO}_{3} \\
(p p m)\end{array}$} \\
\hline & \multicolumn{5}{|c|}{ Seaweed X Sources interaction } & 2007 & 2008 & 2007 & 2008 & 2007 & 2008 \\
\hline Mineral & & & & & & & & 1.88 & .96 & & \\
\hline \begin{tabular}{|l|} 
Rice Straw \\
Compost
\end{tabular} & & 11.14 & 11.65 & 24 & .99 & 08 & 5.13 & 15.59 & 13.16 & 25.54 & 18.50 \\
\hline \begin{tabular}{|l} 
Chicken \\
Manure
\end{tabular} & 687.08619 .36 & 10.64 & 1.07 & 36 & 91 & 5.53 & 5.62 & 13.17 & 15.15 & 30.06 & 30.56 \\
\hline FYM & 659.57706 .32 & & & & & 807 & & 1.84 & 12.29 & 20.30 & 9.70 \\
\hline Mineral & 36 & & & & & 28 & .36 & 0.75 & 10.53 & 23 & 3.14 \\
\hline $\begin{array}{l}\text { Rice Straw } \\
\text { Compost }\end{array}$ & $476.35 \mid 562.28$ & 10.14 & 10.61 & 4.88 & 5.59 & 4.37 & 4.35 & 13.54 & 11.88 & 27.75 & 22.96 \\
\hline \begin{tabular}{|l|l}
$\begin{array}{l}\text { Chicken } \\
\text { Manure }\end{array}$ \\
\end{tabular} & 641.92663 .38 & 9.48 & 9.92 & 4.05 & 4.48 & 4.74 & 4.62 & 12.00 & 13.98 & 34.12 & 33.89 \\
\hline FYM & 612.18625 .38 & 9.98 & 10.29 & 4.54 & 5.08 & .90 & 4.84 & 11.66 & 11.50 & 22.71 & 25.73 \\
\hline LSD at $5 \%$ & \begin{tabular}{|l|l|} 
NS & 22.03 \\
\end{tabular} & 0.09 & & NS & NS & 0.23 & .38 & 0.70 & NS & NS & 1.65 \\
\hline \multicolumn{12}{|c|}{ Seaweed $X$ Rates interaction } \\
\hline \begin{tabular}{l|l|} 
Vith & $100 \%$ \\
\end{tabular} & & & & & & 62 & 80 & 2.26 & 12.17 & 7.38 & .19 \\
\hline $200 \%$ & & 13.04 & & 21 & 80 & 48 & 44 & 3.98 & 13.61 & 3.85 & 0.31 \\
\hline $100 \%$ & 439.9 & 7.49 & & 94 & 61 & 4.16 & 4.17 & 11.34 & 11.31 & 28.78 & 9.20 \\
\hline $200 \%$ & 607.54598 .58 & 12.23 & 11.58 & 4.88 & 5.35 & 4.99 & 4.92 & 12.64 & 12.63 & 38.13 & 36.16 \\
\hline & \begin{tabular}{|l|l|}
16.16 & NS \\
\end{tabular} & 0.05 & 0.04 & NS & NS & NS & NS & NS & NS & NS & NS \\
\hline \multicolumn{12}{|c|}{ Sources $X$ Rates interaction } \\
\hline \begin{tabular}{|l|l|}
$50 \%$ \\
\end{tabular} & 348.53345 .77 & 7.41 & & & & .00 & .08 & 0.67 & 10.02 & 1.74 & 7.74 \\
\hline Mineral & & 12.94 & & & & 78 & 71 & 11.96 & 11.47 & 54.06 & 0.64 \\
\hline Rice Straw $100 \%$ & & 8.7 & & & & & 20 & 13.14 & 11.89 & & 8.00 \\
\hline & & 12.91 & & & & & 28 & 15.99 & 13.15 & 0.29 & 46 \\
\hline \begin{tabular}{|l|l|} 
Chicken & $100 \%$ \\
\end{tabular} & & 8.08 & & & & 83 & .92 & 11.99 & 3.63 & 28.80 & 1.03 \\
\hline Manure & & 12.04 & & & & 44 & 32 & 13.18 & 15.50 & 35.39 & 3.43 \\
\hline \multirow{3}{*}{ FYM } & 528.94563 .90 & 8.45 & & 4.15 & 12 & 62 & .74 & 11.38 & 11.42 & 18.77 & 20.01 \\
\hline & 742.80767 .99 & 12.64 & 10.91 & 5.12 & 53 & 5.35 & 5.40 & 12.12 & 12.37 & 24.23 & 25.42 \\
\hline & \begin{tabular}{|l|l|}
22.85 & 20.60 \\
\end{tabular} & 0.07 & 0.06 & 0.13 & 0.23 & 0.31 & 0.29 & 0.54 & NS & 3.50 & 1.42 \\
\hline
\end{tabular}

\subsection{Effect of the interaction between seaweed extracts and organic nitrogen fertilizer rates}

Data presented in Table (8) illustrate that the interaction between seaweed extracts and organic nitrogen fertilizer rates had significant effects on total yield in both seasons, early yield in the first season and fruit length in second season. While insignificant differences has been detected as dry matter, TSS, vitamin C and nitrate content in the fruits of summer squash in the two seasons, achieved higher total yield and fruits quality were produced by using seaweed extracts with addition at $200 \%$ of recommended rate comparison with plants treated at $100 \%$ of recommended rate in the two seasons. Total yield and fruits quality of summer squash were the greatest values by applying seaweed extracts combined with $200 \%$ of recommended rate. While the lowest nitrate content in fruits was observed with foliar application seaweed extracts at $100 \%$ rate. These results might be due to increases in vegetative growth characters and dry matter (Table 4), and finally reflected on yield and improved fruits quality. 


\subsection{Effect of the interaction between organic nitrogen fertilizer sources and rates}

Data in Table (8) show the interaction effect of organic nitrogen fertilizer sources and rates on summer squash yield and fruits quality. This interaction caused significant increase in both seasons, in early yield, total yield, dry matter and TSS, except vitamin $\mathrm{C}$ in the fruits in the second season only. The maximum early yield were obtained when summer squash plants were fertilized with FYM at $200 \%$ and total yield and fruit quality with compost manure at $200 \%$ of recommended rate/fed. compared with other treatments in the two seasons. On the other hand, the minimum early yield, total yield and fruits quality were recorded with plants received mineral nitrogen fertilizer at $50 \%$ of recommended rate in both seasons. The increase in total yield and fruits quality characters might be due to the increase in the vegetative growth parameters of the plant (Table 4), which increases the photosynthetic rates leading to an increase of the assimilation rates and also stated that addition of compost manure had more nutrients which may increase its availability for plant and improved the soil structure and encouraged the plant to have good root development by improving the aeration in the soil, all beneficial effects might lead to higher yield of summer squash. In this respect Seyedbagheri (1999), found that applying compost at rate of $25 \mathrm{~m}^{3} /$ ha gave the highest yield of potato plant.

Data in the same Table clearly indicate that nitrate content in the fruits was affected due to the different types of organic nitrogen fertilizer sources and rates in both seasons. The lowest level of nitrate in summer squash fruits was resulted from using FYM at $100 \%$ followed by using compost manure at $100 \%$ of recommended rate in the two seasons. The steady release of nitrogen from organic manures in form of ammonium at relatively slow release which probably caused low nitrate contents in the fruits. The obtained results are in agreement with those of Clark et al. (1999), Abd El-Kawy (2003), Awad (2007) and Ibrahim and Selim (2007).

\section{7. Effect of the interaction among seaweed extracts, organic nitrogen fertilizer sources and rates}

Interaction effects of studied factors on summer squash yield and fruits quality are presented in Table (9), data indicate that early yield, total yield were significantly influenced by the interaction, in both seasons and nitrate in the second season only but dry matter, TSS and vitamin C were insignificantly affected in the two seasons. Plants sprayed of seaweed extracts with supplied organic nitrogen fertilizer as a chicken manure at 200 $\%$ and/or FYM at $200 \%$ of recommended rates produced the highest early yield in both seasons respectively, while total yield was recorded with foliar application of seaweed combination compost manure at $200 \%$ of recommended rate. While the lowest level of nitrate in summer squash fruits was resulted from the plants received FYM at $100 \%$ followed by compost manure at $100 \%$ of recommended rate combined with spraying with seaweed in the two seasons. 
Table (9): Effect of the interaction among seaweed extracts, organic nitrogen fertilizer sources and rates on yield and fruit quality parameters of summer squash plants during 2007 and 2008 seasons.

\begin{tabular}{|c|c|c|c|c|c|c|c|c|}
\hline \multicolumn{3}{|c|}{ Characters } & $\begin{array}{c}\text { Early yield } \\
\text { (kg/fed.) }\end{array}$ & $\begin{array}{c}\text { Total yield } \\
\text { (ton/fed.) }\end{array}$ & \begin{tabular}{|c|} 
Dry \\
matter \\
$(\%)$
\end{tabular} & $\begin{array}{l}\text { TSS } \\
(\%)\end{array}$ & $\begin{array}{c}\text { V.C } \\
(\mathrm{mg} / 100 \mathrm{~g} \\
\text { F.W })\end{array}$ & $\begin{array}{c}\mathrm{NO}_{3} \\
(\mathrm{ppm})\end{array}$ \\
\hline Seaweed & Sources & & & & 20072008 & & $2007 \mid 2008$ & \begin{tabular}{l|l|l}
2007 & 2008
\end{tabular} \\
\hline \multirow{5}{*}{ With } & Mineral & \begin{tabular}{|l|}
$50 \%$ \\
$100 \%$ \\
\end{tabular} & $\frac{355 .}{460 .}$ & & & & 12.5011 .75 & \\
\hline & & $100 \%$ & & 8.17 & \begin{tabular}{|l|l|}
4.86 & 5.65 \\
\end{tabular} & 4.57 & 13.9312 .48 & 5.94 \\
\hline & & 200 & & & \begin{tabular}{|l|l|}
5.61 & 6.33 \\
\end{tabular} & \begin{tabular}{|l|l|}
5.60 & 5.57 \\
\end{tabular} & 17.2513 .8 & 21.05 \\
\hline & \begin{tabular}{|l} 
Chicke \\
Manur
\end{tabular} & $\frac{100}{200}$ & 0531 & \begin{tabular}{|c|c|}
8.86 & 9.21 \\
12.43 & 12.92 \\
\end{tabular} & \begin{tabular}{|l|l|}
4.04 & 4.66 \\
4.68 & 5.16 \\
\end{tabular} & \begin{tabular}{|l|l|}
5.10 & 5.37 \\
5.97 & 5.86 \\
\end{tabular} & \begin{tabular}{|l|l|}
12.55 & 14.22 \\
13.78 & 16.08 \\
\end{tabular} & \\
\hline & FYM & & & & \begin{tabular}{|l|l|}
4.25 & 5.33 \\
5.23 & 5.80 \\
\end{tabular} & & \begin{tabular}{|l|l|}
11.28 & 11 \\
12.40 & 12
\end{tabular} & \\
\hline \multirow{5}{*}{ Without } & Mineral & \begin{tabular}{|l|}
$50 \%$ \\
$100 \%$ \\
\end{tabular} & & & & & \begin{tabular}{|l|l|}
10.08 & 9.87 \\
11.42 & 11.18
\end{tabular} & \\
\hline & & $100 \%$ & & \begin{tabular}{l|l}
97 & 8.37 \\
\end{tabular} & \begin{tabular}{|l|l|}
4.51 & 5.24 \\
\end{tabular} & \begin{tabular}{|l|l|}
3.63 & 3.72 \\
\end{tabular} & 12.3511 .3 & 0.50 \\
\hline & $\begin{array}{l}\text { Str } \\
\text { Co }\end{array}$ & & & & \begin{tabular}{|l|l|l|}
5.26 & 5.93 \\
\end{tabular} & 5.104 & 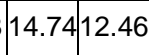 & \\
\hline & & $100 \%$ & & & & & 11.4313 .0 & \\
\hline & $F Y$ & $\frac{100}{200}$ & & & \begin{tabular}{|l|l|}
4.05 & 4.90 \\
5.02 & 5.25 \\
\end{tabular} & & $|11.83| 11.0$ & \\
\hline SD at 5 & & & & \begin{tabular}{|l|l|l|}
0.10 & 0.08 \\
\end{tabular} & \begin{tabular}{|l|l|} 
NS & NS \\
\end{tabular} & \begin{tabular}{|l|l|} 
NS & NS \\
\end{tabular} & \begin{tabular}{|l|l|} 
NS & NS \\
\end{tabular} & 2.00 \\
\hline
\end{tabular}

\section{Mineral contents (NPK)}

\subsection{Effect of seaweed extracts}

Data in Table (10) clearly illustrate that the foliar application of seaweed extracts significantly affected contents of $\mathrm{N}, \mathrm{P}$ and $\mathrm{K}$ in both leaves and fruits. The highest respect values of macronutrients (N,P and $K$ ) were obtained from the plants which were foliar sprayed by seaweed extracts in the two seasons. The increments of N, P and K contents in the leaves and fruits might be attributed to organic and mineral elements constituents of seaweed extracts in (Table 3). This trend is similar to that of Hamed (1997), El-Saei and Tartoura (2004), Tartoura and El-Saei (2005 and 2007).

\subsection{Effect of organic nitrogen fertilizer sources}

Data presented in Table (10) demonstrate that N, P and $\mathrm{K}$ percentage in both leaves and in fruits of summer squash were significantly influenced by different types of organic nitrogen fertilizer sources in the two seasons. The highest values of nitrogen and potassium percentage in the leaves and in the fruits were obtained when nitrogen fertilizer was added as a source of compost manure, except in the first season with nitrogen content in the leaves. While, the differences did not reach to the level of significance for nitrogen and potassium percentage in the leaves and in the fruits between compost manure and/or nitrogen as mineral fertilizer in both seasons. The highest values of phosphorus percentage in the leaves and in the fruits were recorded with the plants which received chicken manure compared with other sources of organic nitrogen fertilizer in the two seasons. The increment uptake of $\mathrm{N}, \mathrm{P}$ and $\mathrm{K}$ in the leaves and fruits may be due to higher availability of the nutrients which increase in the fertilizer application (Table 2), which ultimately resulted in better root growth and increased physiological activity of 
roots to absorb the nutrients through decomposition of organic matter that lead to increase their concentration in plant leaves and fruits. These results are in harmony with those obtained by Shehata (2001) on squash and ElMansi et al.(2004) on pea.

Table (10): Effect of seaweed extracts, organic nitrogen fertilizer sources and rates on NPK \% in both leaves and fruits of summer squash plants during 2007 and 2008 seasons.

\begin{tabular}{|c|c|c|c|c|c|c|c|c|c|c|c|}
\hline \multirow{3}{*}{\begin{tabular}{|l|} 
Characters \\
Treatments \\
\end{tabular}} & \multicolumn{6}{|c|}{ Leaves } & \multicolumn{5}{|c|}{ Fruits } \\
\hline & $\begin{array}{r}N \\
2007 \\
\end{array}$ & \begin{tabular}{|l|}
$\%$ \\
2008 \\
\end{tabular} & \multirow[t]{2}{*}{\begin{tabular}{|l|}
\multicolumn{2}{|r|}{$\mathbf{P}^{2}$} \\
2007 \\
\end{tabular}} & \multirow[t]{2}{*}{$\frac{\%}{2008}$} & \multicolumn{2}{|c|}{\begin{tabular}{|l|l|}
\multicolumn{2}{|c}{$K \%$} \\
2007 & 2008 \\
\end{tabular}} & \multirow[t]{2}{*}{\begin{tabular}{r|}
$N^{c}$ \\
2007 \\
\end{tabular}} & \multirow[t]{2}{*}{$\begin{array}{l}\% \% \\
2008 \\
\end{array}$} & \multirow[t]{2}{*}{\begin{tabular}{|l|l|}
\multicolumn{2}{|c|}{$\mathbf{P} \%$} \\
2007 & 2008 \\
\end{tabular}} & \multirow{2}{*}{\multicolumn{2}{|c|}{\begin{tabular}{|c|c|}
\multicolumn{2}{|c|}{ K \% } \\
2007 & 2008 \\
\end{tabular}}} \\
\hline & & & & & & & & & & & \\
\hline With & 2.54 & 2.97 & 0.287 & 0.300 & 3.69 & 3.81 & 2.04 & 2.17 & \begin{tabular}{|l|l|}
0.238 & 0.257 \\
\end{tabular} & 2.73 & 2.70 \\
\hline Without & 2.26 & 2.72 & 0.260 & 0.275 & 3.55 & 3.67 & 1.92 & 1.97 & \begin{tabular}{|l|l|}
0.221 & 0.233 \\
\end{tabular} & \begin{tabular}{|l|}
2.62 \\
\end{tabular} & 2.58 \\
\hline F Test & $x^{*}$ & & & * & & & NS & & NS ${ }^{*}$ & & \\
\hline \multicolumn{12}{|l|}{ B-Sources: } \\
\hline Mineral & 2.57 & 2.53 & 0.238 & 0.253 & 3.53 & 3.64 & 2.34 & 2.42 & $\begin{array}{l}0.198 \\
0.216 \\
\end{array}$ & 2.37 & 2.37 \\
\hline Rice Straw & 2.49 & 3.11 & 0.260 & 0.278 & 3.89 & 4.06 & 2.21 & 2.31 & \begin{tabular}{ll|l}
0.226 & 0.247
\end{tabular} & 2.84 & 2.83 \\
\hline Chicken & 2.13 & 2.82 & 0.324 & 0.338 & 3.36 & 3.48 & 1.56 & 1.62 & \begin{tabular}{l|l|l|}
0.252 & 0.263 \\
\end{tabular} & 2.63 & 2.56 \\
\hline & 2.40 & 2.92 & 0.27 & 0.281 & 3.70 & 3.8 & 1.81 & 1.95 & \begin{tabular}{|l|l|}
0.242 & 0.255 \\
\end{tabular} & 2.85 & 2.79 \\
\hline LSD at $5 \%$ & 0.12 & 0.06 & 0.001 & 0.00 & 0.10 & 0.09 & 0.11 & 0.06 & \begin{tabular}{|l|l|}
0.002 & 0.002 \\
\end{tabular} & 0.07 & 0.07 \\
\hline \multicolumn{12}{|l|}{ C-Rates: } \\
\hline $100 \%$ & 1.98 & 2.36 & 0.24 & $0 . \angle 5$ & 3.36 & 3.51 & 1.73 & 1.81 & 0.20 & 2.24 & 2.19 \\
\hline & 2.81 & 3.33 & 0.301 & 0.318 & 3.88 & 3.98 & 2.23 & 2.34 & \begin{tabular}{ll|l}
0.250 & 0.270 \\
\end{tabular} & 3.11 & 3.09 \\
\hline Test & & & & & & & & & & & \\
\hline
\end{tabular}

\subsection{Effect of organic nitrogen fertilizer rates}

Data in Table (10) clearly illustrate that the addition of organic rates significantly affected the contents $\mathrm{N}, \mathrm{P}$ and $\mathrm{K}$ in both leaves and fruits in both seasons. The maximum values of these macronutrients were obtained from application at $200 \%$ of recommended rate in the two seasons. These results are in line with Kotb (1994), Saleh et al. (2007) on tomato, Shaheen et al. (2007) on onion.

\subsection{Effect of the interaction between seaweed extracts and organic nitrogen fertilizer sources}

The effect of the interaction between seaweed extracts and organic nitrogen fertilizer sources on N, P and K contents in both leaves and fruits of

summer squash plants is shown in Table (11) reveal that there was significant effect on $\mathrm{N}, \mathrm{P}$ and $\mathrm{K}$ contents. The abovementioned interaction did not show any significant effect on $K$ in the leaves and $P$ in fruits in both seasons and $K$ in the fruit in first season. The highest values of $N, P$ and $K$ were obtained when plants were sprayed by seaweed extracts with addition three sources of mineral nitrogen, chicken manure and compost manure respectively in both seasons. These effect could be due to organic and mineral elements constituents of seaweed extracts (Table 3 ). This trend is similar to that of Nelson and Van Staden (1984) and Hamed (1997) who found that seaweed extracts significantly increased $P$ and $K$ content compared with control, while, $\mathrm{N}$ content was not changed on pepper plants.

\subsection{Effect of the interaction between seaweed extracts organic nitrogen fertilizer rates}

Concerning the interaction effect between seaweed extracts and organic nitrogen fertilizer rate on mineral composition of the leaves and fruits 
of summer squash plants, data in Table (11) indicated that foliar spraying of seaweed in the presence organic nitrogen fertilizer rates caused obvious increase in the leaves and fruits of summer squash. These increases were significant in the case of $\mathrm{N}$ and $\mathrm{K}$ in leaves in the first season, $\mathrm{P}$ in the leaves as well as NP in fruits the second season. The greatest content macroelement, was connected when the plants gave seaweed extracts with organic manure at $200 \%$ of recommended rate in both seasons.

\subsection{Effect of the interaction between organic nitrogen fertilizer sources} and rates

Data in the same Table (11) explain that the interaction between organic nitrogen fertilizer sources and rates had a positive significant effect of content $\mathrm{N}$ in the leaves and fruits, $\mathrm{P}$ in the leaves and $\mathrm{K}$ in fruits in both seasons. but no-significant affected was observed in the case of $P$ content in fruits in both seasons. Also, $\mathrm{K}$ content in leaves was higher in the second season.

Table (11): Effect of the interactions (seaweed extracts $X$ organic nitrogen fertilizer sources), (seaweed extracts $X$ rates) and (organic nitrogen sources $X$ rates) on NPK \% in both leaves and fruits of summer squash plants during 2007 and 2008 seasons.

\begin{tabular}{|c|c|c|c|c|c|c|c|c|c|c|c|c|c|}
\hline \multirow{2}{*}{\multicolumn{2}{|c|}{\begin{tabular}{|l|} 
Characters \\
Treatments \\
Soamon Y Courcoc int
\end{tabular}}} & \multicolumn{6}{|c|}{ Leaves } & \multicolumn{6}{|c|}{ Fruits } \\
\hline & & \multirow{2}{*}{\multicolumn{2}{|c|}{\begin{tabular}{|r|r|}
\multicolumn{2}{|c|}{$N \%$} \\
2007 & 2008 \\
\end{tabular}}} & \multicolumn{2}{|c|}{\begin{tabular}{|l|l|}
\multicolumn{2}{|c|}{$P$ \% } \\
2007 & 2008 \\
\end{tabular}} & \multicolumn{2}{|c|}{\begin{tabular}{|l|l|}
\multicolumn{2}{|c|}{ K \% } \\
2007 & 2008 \\
\end{tabular}} & \multicolumn{2}{|c|}{\begin{tabular}{l|l}
\multicolumn{2}{c}{$N \%$} \\
2007 & 2008 \\
\end{tabular}} & \multicolumn{2}{|c|}{\begin{tabular}{|c|l|}
\multicolumn{2}{|c|}{$P$ \% } \\
2007 & 2008 \\
\end{tabular}} & \multicolumn{2}{|c|}{\begin{tabular}{|l|l|}
\multicolumn{2}{|c|}{$K \%$} \\
2007 & 2008 \\
\end{tabular}} \\
\hline \multicolumn{12}{|c|}{ Seaweed X Sources interaction } & & \\
\hline \multirow{4}{*}{ With } & Mineral & 2.70 & 2.65 & 0.218 & 0.267 & 3.61 & 3.70 & 2.45 & 2.55 & 0.202 & 0.223 & 2.46 & 2.47 \\
\hline & $\begin{array}{l}\text { Rice Straw } \\
\text { Compost }\end{array}$ & 2.67 & 3.24 & 0.272 & 0.288 & 3.94 & 4.15 & 2.27 & 2.41 & 0.235 & 0.262 & 2.89 & 2.88 \\
\hline & \begin{tabular}{|l|} 
Chicken \\
Manure
\end{tabular} & 2.27 & 2.94 & 0.343 & 0.360 & 3.44 & 3.54 & 1.60 & 1.66 & 0.267 & 0.278 & 2.67 & 2.56 \\
\hline & FYM & 2.52 & 3.04 & 0.283 & 0.287 & 3.76 & 3.85 & 1.24 & 2.07 & 0.248 & 0.265 & 2.89 & 2.88 \\
\hline \multirow{4}{*}{ Without } & Mineral & 2.43 & 2.42 & 0.228 & 0.240 & 3.45 & 3.58 & 2.22 & 2.29 & 0.193 & 0.208 & 2.28 & 2.27 \\
\hline & $\begin{array}{l}\text { Rice Straw } \\
\text { Compost } \\
\end{array}$ & 2.31 & 2.97 & 0.248 & 0.268 & 3.84 & 3.96 & 2.15 & 2.21 & 0.217 & 0.232 & 2.80 & 2.79 \\
\hline & $\begin{array}{l}\text { Chicken } \\
\text { Manure }\end{array}$ & 2.01 & 2.69 & 0.305 & 0.317 & 3.28 & 3.41 & 1.52 & 1.58 & 0.237 & 0.247 & 2.60 & 2.56 \\
\hline & FYM & 2.28 & 2.81 & 0.258 & 0.275 & 3.63 & 3.74 & 1.79 & 1.82 & 0.237 & 0.245 & 2.82 & 2.71 \\
\hline \multicolumn{2}{|c|}{ LSD at $5 \%$} & 0.16 & 0.09 & 0.001 & 0.001 & NS & NS & 0.15 & 0.08 & NS & NS & NS & 0.10 \\
\hline \multicolumn{14}{|c|}{ Seaweed X Rates interaction } \\
\hline \multirow{2}{*}{ With } & $100 \%$ & 2.08 & 2.49 & 0.259 & 0.268 & 3.39 & 3.56 & 1.75 & 1.88 & 0.214 & 0.227 & 2.30 & 2.25 \\
\hline & $200 \%$ & 2.99 & 3.45 & 0.314 & 0.332 & 3.98 & 4.06 & 2.32 & 2.46 & 0.262 & 0.287 & 3.16 & 3.14 \\
\hline \multirow{2}{*}{ Without } & $100 \%$ & 1.88 & 2.22 & 0.232 & 0.247 & 3.32 & 3.45 & 1.70 & 1.74 & 0.203 & 0.213 & 2.17 & 2.13 \\
\hline & $200 \%$ & 2.63 & 3.22 & 0.288 & 0.303 & 3.78 & 3.90 & 2.14 & 2.21 & 0.238 & 0.253 & 3.07 & 3.03 \\
\hline \multicolumn{2}{|c|}{ LSD at $5 \%$} & 0.11 & NS & NS & 0.001 & 0.077 & NS & NS & 0.05 & NS & 0.002 & NS & NS \\
\hline \multicolumn{14}{|c|}{ Sources X Rates interaction } \\
\hline \multirow{2}{*}{ Mineral } & $50 \%$ & 1.75 & 1.81 & 0.217 & 0.230 & 3.27 & 3.37 & 2.14 & 2.20 & 0.185 & 0.193 & 1.66 & 1.72 \\
\hline & $100 \%$ & 3.38 & 3.26 & 0.260 & 0.277 & 3.79 & 3.91 & 2.53 & 2.63 & 0.220 & 0.238 & 3.08 & 3.02 \\
\hline \multirow{4}{*}{\begin{tabular}{|l|} 
Rice Straw \\
Compost \\
Chicken \\
Manure \\
\end{tabular}} & $100 \%$ & 2.15 & 2.55 & 0.232 & 0.245 & 3.63 & 3.83 & 2.02 & 2.08 & 0.210 & 0.228 & 2.39 & 2.35 \\
\hline & $200 \%$ & 2.83 & 3.66 & 0.288 & 0.312 & 4.15 & 4.29 & 2.40 & 2.53 & 0.242 & 0.265 & 3.30 & 3.32 \\
\hline & $100 \%$ & 1.95 & 2.65 & 0.300 & 0.313 & 3.18 & 3.26 & 1.21 & 1.25 & 0.232 & 0.233 & 2.38 & 2.28 \\
\hline & $200 \%$ & 2.32 & 2.98 & 0.343 & 0.363 & 3.54 & 3.69 & 1.91 & 1.98 & 0.272 & 0.292 & 2.89 & 2.84 \\
\hline \multirow{2}{*}{ FYM } & $100 \%$ & 2.09 & 2.41 & 0.233 & 0.243 & 3.35 & 3.56 & 1.54 & 1.69 & 0.218 & 0.227 & 2.52 & 2.42 \\
\hline & $200 \%$ & 2.72 & 3.44 & 0.308 & 0.318 & 4.04 & 4.04 & 2.09 & 2.20 & 0.267 & 0.283 & 3.18 & 3.17 \\
\hline \multicolumn{2}{|l|}{ LSD at $5 \%$} & 0.15 & 0.08 & 0.001 & 0.001 & 0.110 & NS & 0.15 & 0.07 & NS & NS & 0.10 & 0.13 \\
\hline
\end{tabular}


There were in general superior enhancing of $\mathrm{N}, \mathrm{P}$ and $\mathrm{K}$ contents in the leaves and fruits of summer squash when nitrogen was added as a source of mineral fertilizer at $100 \%$, chicken manure and compost manure at $200 \%$ of recommended rates in both season. On the other hand, lower $\mathrm{N}, \mathrm{P}$ and $\mathrm{K}$ contents in the leaves and fruits were recorded by the plants fertilized with mineral fertilizer at $50 \%$ and/or chicken manure at $100 \%$ of recommended rates compared with other treatments in two seasons. The increment uptake of $\mathrm{N}, \mathrm{P}$ and $\mathrm{K}$ in the leaves and fruits may be due to higher availability of the nutrients which increase in fertilizer application which ultimately resulted in better root growth and increased physiological activity of root to absorb the nutrients through decomposition of organic matter that led to increase their concentration in plant leaves and fruits this results are in harmony with those obtained by El-Sherif (2006) found that in and $\mathrm{K}$ in leaves were significantly affected by compost levels treatments when cucumber plants grown in highest level, i.e., $6 \mathrm{t} / \mathrm{fed}$. had higher level of $\mathrm{N}$ and $\mathrm{P}$ compared with other two level 2 and $4 \mathrm{t} /$ feddan.

\subsection{Effect of the interaction among seaweed extracts, organic nitrogen}

\section{fertilizer sources and rates}

As for the effect of interaction among between seaweed extracts and organic nitrogen fertilizer sources and rates on mineral contents (N, P and $\mathrm{K}$ ) in the leaves and fruits of summer squash, data in Table (12) clearly indicated that there were no-significant effects for the interaction in both seasons, while $\mathrm{K}$ in leaves and $\mathrm{P}$ in the fruits contents were significantly affected by the interaction in the first and second season respectively.

Table (12): Effect of the interaction among seaweed extracts, organic nitrogen fertilizer sources and rates on NPK \% in both leaves and fruits of summer squash plants during 2007 and 2008 seasons.

\begin{tabular}{|c|c|c|c|c|c|c|c|c|c|c|c|c|c|c|}
\hline \multirow{2}{*}{\multicolumn{3}{|c|}{ Characters }} & \multicolumn{6}{|c|}{ Leaves } & \multicolumn{6}{|c|}{ Fruits } \\
\hline & & & \multicolumn{2}{|c|}{$\mathbf{N} \%$} & \multicolumn{2}{|c|}{$\mathbf{P} \%$} & \multicolumn{2}{|c|}{ K \% } & \multicolumn{2}{|c|}{ N \% } & \multicolumn{2}{|c|}{ P \% } & \multicolumn{2}{|c|}{ K \% } \\
\hline Seaweed & sources & Rates & 2007 & 2008 & 2007 & 2008 & 2007 & 2008 & 2007 & 2008 & 2007 & 2008 & 2007 & 2008 \\
\hline \multirow{8}{*}{ With } & Mineral & $50 \%$ & 1.86 & 1.96 & 0.227 & 0.243 & 3.37 & 3.43 & 2.19 & 2.25 & 0.183 & 0.207 & \begin{tabular}{|l|}
1.77 \\
\end{tabular} & 1.81 \\
\hline & & $100 \%$ & 3.53 & 3.35 & 0.270 & 0.290 & 3.86 & 3.97 & 2.72 & 2.85 & 0.220 & 0.240 & 3.15 & 3.13 \\
\hline & Rice & $100 \%$ & 2.26 & 2.72 & 0.243 & 0.250 & 3.65 & 3.92 & 2.06 & 2.13 & 0.217 & 0.237 & 2.43 & 2.36 \\
\hline & $\begin{array}{l}\text { Straw } \\
\text { Compost }\end{array}$ & $200 \%$ & 3.07 & 3.76 & 0.300 & 0.327 & 4.22 & 4.38 & 2.48 & 2.68 & 0.253 & 0.287 & 3.36 & 3.39 \\
\hline & & $100 \%$ & 2.06 & 2.77 & 0.317 & 0.333 & 3.24 & 3.29 & 1.24 & 1.28 & 0.237 & 0.233 & 2.42 & 2.33 \\
\hline & Manure & $200 \%$ & 2.47 & 3.12 & 0.370 & 0.387 & 3.63 & 3.80 & 1.96 & 2.04 & 0.297 & 0.323 & 2.91 & 2.79 \\
\hline & FYM & $100 \%$ & 2.16 & 2.53 & 0.250 & 0.247 & 3.32 & 3.61 & 1.53 & 1.86 & 0.220 & 0.233 & 2.57 & 2.49 \\
\hline & & & 2.88 & 3.55 & 0.317 & 0.327 & 4.20 & 4.10 & 2.15 & 2.28 & 0.277 & 0.297 & 3.20 & 3.26 \\
\hline \multirow{8}{*}{ Without } & Mineral & $50 \%$ & 1.65 & 1.66 & 0.207 & 0.217 & 3.18 & 3.31 & 2.09 & 2.16 & 0.167 & 0.180 & 1.54 & 1.63 \\
\hline & & $100 \%$ & 3.23 & 3.17 & 0.250 & 0.263 & 3.72 & 3.84 & 2.35 & 2.42 & 0.220 & 0.237 & 3.02 & 2.91 \\
\hline & Rice & $100 \%$ & 2.04 & 2.38 & 0.220 & 0.240 & 3.60 & 3.73 & 1.98 & 2.03 & 0.203 & 0.220 & 2.35 & 2.33 \\
\hline & $\begin{array}{l}\text { Straw } \\
\text { Compost }\end{array}$ & $200 \%$ & 2.58 & 3.55 & 0.277 & 0.297 & 4.08 & 4.20 & 2.31 & 2.38 & 0.230 & 0.243 & 3.24 & 3.25 \\
\hline & & $100 \%$ & 1.83 & 2.85 & 0.283 & 0.293 & 3.12 & 3.23 & 1.18 & 1.23 & 0.227 & 0.233 & 2.34 & 2.23 \\
\hline & & & 2.16 & 2.84 & 0.327 & 0.340 & 3.44 & 3.59 & 1.86 & 1.92 & 0.247 & 0.260 & 2.86 & 2.88 \\
\hline & FYM & $100 \%$ & 2.01 & 2.29 & 0.217 & 0.240 & 3.38 & 3.52 & 1.55 & 1.53 & 0.217 & 0.220 & 2.47 & 2.35 \\
\hline & & $200 \%$ & 2.55 & 3.33 & 0.300 & 0.310 & 3.88 & 3.97 & 2.63 & 2.12 & 0.257 & 0.270 & 3.17 & 3.07 \\
\hline \multicolumn{3}{|l|}{ LSD at $5 \%$} & NS & NS & NS & NS & 0.155 & NS & NS & NS & NS & 0.002 & NS & NS \\
\hline
\end{tabular}




\section{Economic estimation}

Results in Table (13) show that the maximum net return (4992 and 4854 L.E./fed) were obtained with foliar spraying by seaweed extracts at 1 $\mathrm{kg} / \mathrm{fed}$ in combination with $200 \%$ of FYM $(10.500 \mathrm{t} / \mathrm{fed})$, followed by rice straw compost at $200 \%(8.800 \mathrm{t} / \mathrm{fed})$ of recommended rate/fed comparison with other treatments, respectively. The treatment of $100 \%$ mineral fertilization (60 kg N/fed) is considered a base for economic evaluation.

Table (13): Estimate of additional net return for all treatments.

\begin{tabular}{|c|c|c|c|c|c|c|c|}
\hline \multicolumn{3}{|c|}{ Treatments } & \multirow{2}{*}{$\begin{array}{c}\text { Total } \\
\text { yield } \\
\text { (t/fed) * }\end{array}$} & \multirow{2}{*}{$\begin{array}{l}\text { Total cost } \\
\text { (L.E./fed) }\end{array}$} & \multirow{2}{*}{ 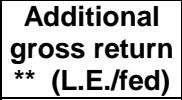 } & \multirow{2}{*}{\begin{tabular}{|c|} 
Additional \\
net (L.E./fed)
\end{tabular}} & \multirow[t]{2}{*}{ Order } \\
\hline Seaweed & sources & Rates & & & & & \\
\hline \multirow{8}{*}{ With } & \multirow{2}{*}{ Mineral } & $50 \%$ & 8.980 & 1505 & 2395 & 890 & 15 \\
\hline & & $100 \%$ & 13.495 & 1866 & 3523 & 1637 & 13 \\
\hline & \multirow{2}{*}{$\begin{array}{l}\text { Rice Straw } \\
\text { Compost }\end{array}$} & $100 \%$ & 8.820 & 1774 & 4560 & 2786 & 8 \\
\hline & & $200 \%$ & 13.925 & 2258 & 7112 & 4854 & 2 \\
\hline & \multirow{2}{*}{\begin{tabular}{|l} 
Chicken \\
Manure
\end{tabular}} & $100 \%$ & 9.035 & 2114 & 4560 & 2446 & 11 \\
\hline & & $200 \%$ & 12.315 & 2938 & 6487 & 3549 & 5 \\
\hline & \multirow{2}{*}{ FYM } & $100 \%$ & 9.235 & 1540 & 4767 & 3227 & 6 \\
\hline & & $200 \%$ & 13.315 & 1815 & 6807 & 4992 & 1 \\
\hline \multirow{8}{*}{ Without } & \multirow{2}{*}{ Mineral } & $50 \%$ & 7.050 & 1355 & 1763 & 408 & 16 \\
\hline & & $100 \%$ & 13.025 & 1116 & 3256 & 1540 & 14 \\
\hline & \multirow{2}{*}{$\begin{array}{l}\text { Rice Straw } \\
\text { Compost }\end{array}$} & $100 \%$ & 8.170 & 1624 & 4085 & 2461 & 10 \\
\hline & & $200 \%$ & 12.580 & 2108 & 6290 & 4182 & 4 \\
\hline & \multirow{2}{*}{$\begin{array}{l}\text { Chicken } \\
\text { Manure }\end{array}$} & $100 \%$ & 7.530 & 1964 & 3765 & 1801 & 12 \\
\hline & & $200 \%$ & 11.865 & 2788 & 5932 & 3144 & 7 \\
\hline & \multirow{2}{*}{ FYM } & $100 \%$ & 8.015 & 1390 & 4007 & 2617 & 9 \\
\hline & & $200 \%$ & 12.255 & 1665 & 6127 & 4462 & 3 \\
\hline
\end{tabular}

* Total fruits yield as an average of two seasons.

** Additional costs was estimated according to the following prices: Prices of; $N=$ L.E. = $3.6 / \mathrm{kg}$ (ammonium nitrate), $\mathrm{P}_{2} \mathrm{O}_{5}=\mathrm{L} . \mathrm{E} .=4 / \mathrm{kg}$ (normal calcium super phosphate), $\mathrm{K}_{2} \mathrm{O}=$ L.E. $=5 / \mathrm{kg}$ (potassium sulphate), seaweed extracts $=$ L.E. $=150=1 \mathrm{~kg} / \mathrm{fed}$, rice straw compost $=$ L.E. = 110/ton, chicken manure with litter $=$ L.E. $=160 /$ ton, FYM = L.E. = $50 /$ ton. Price of product from chemical fertilizer $=$ L.E. $=250$ /ton and price of product from organic manure = L.E. = 500/ton

\section{Conclusion}

Generally, the obtained results indicated that foliar spraying by seaweed extracts at $1 \mathrm{~kg} / \mathrm{fed}$., combination with compost manure at $200 \%$ of recommended rate /fed. It is the most effective treatment to gain adequate yield with better quality on summer squash plants compared with other different organic. While FYM at $200 \%$ of recommended rate was obtained raising profit economic estimation.

\section{REFERENCES}

Abd El-Kawy, T.F. (2003). The effect of some organic and inorganic fertilizers on plant growth and fruit quality of cucumber plant under plastic houses. M. Sc. Thesis, Fac. Agric. Ain Shams Univ., Egypt. 
Abdelhamid, M.T., T. Horiuchi and S. Oba, (2004). Composting of rice straw with oilseed rape cake and poultry manure and its effects on faba bean (Vicia faba L.) growth and soil properties. Bio Resource Technology, 93(2): 183-189.

Abou-Hussein, S.D.; U.A. El-Bahiry; I. El-Oksha and M.A. Kalafallah (2002). Effect of compost, biofertilizer and chicken manure on nutrient content and tuber quality of potato crop. Egypt. J. Hort., 29 (1): 117-133.

Alvarez, M. A.; S. Gagne and H. Antoun, (1995). Effect of compost rhizosphere on micro flora of the tomato and on the incidence of plant growth- promoting rhizobacteria. Applied Environmental Microbiology, 61 (1): $194-199$.

Aly, H.H. (2002). Studies on keeping quality and storability of cucumber fruit under organic farming system in greenhouses. M.Sc. Thesis, Fac. Agric. Cairo Univ., Egypt.

Awad, El.M.M. (2007). Effect of different sources and rates of compost on growth, yield and quality of potato crop. Egyptian J. Agric. Res. 85: (3) :987- 998.

A.O.A.C. Association of Official Analysts Chemists (1990). Official methods of analysis, $1^{\text {th }}$ Ed. Washington, D.C., USA.

Bayoumi, Y.A. (2005). Studies on organic production of tomato crop. Ph. D. Thesis, Fac. Agric., Kafr El-Sheikh, Tanta Univ., Egypt.

Bayoumi, Y.A. and Y.M. Hafez (2006). Effect of organic fertilizers combined with benzo $(1,2$ and 3$)$ thiadiazole -7 carbathioic acids - methyl ester (BTH) on the cucumber powdery mildew and the yield production. Acta Biologica Szegediensis, 50 (3-4): 131-136.

Black, C. A. (1965). "Methods of Soil Analysis". Part I- Physical and mineralogical properties. A. S. A. Madison Wisc., USA.

Bremner, J.M. and C.S. Muluaney (1982). Total nitrogen, In: Page, A.L., R.H. Miller and D.R. Heeney (Eds.), Methods of soil analysis. Part 2. pp. 595-624, J. Amer. Soc. Agron., Madison, W.I., USA.

Clark, M.S. ; W.R. Horwath; C. Shennan; K.M. Scow; W.T. Lantani and H. Ferris (1999). Nitrogen, weeds and water as yield limiting factors in conventional, low - input and organic tomato systems. Agric. Ecosys. \& Environ., 73: 257-270.

Codex A.C. (2001). Definition of organic farming. Guidelines for the production, Processing, Labeling and Marketing of organically Produced Foods, CAC/GL 32- 1999, point 7.

Crouch, I.J. and J. Van Staden (1991). Evidence for rooting factors in a seaweed concentrate prepared from Ecklonia maxima. J. Plant Physiol.,137 (3): 319-322.

Crouch, I.J. and J. Van Staden (1992). Effect of seaweed concentrate on the establishment and yield of greenhouse tomato plants. J. App. Phycology. 4: $241-296$.

Duxbury, J. M. ; M.S. Smith and J.W. Doran (1989). Soil organic matter as a source and sink of plant nutrients. In D.C. Coleman, J.M. Oades \& G. Uehara, eds. Dynamics of soil organic matter in tropical ecosystem, pp 33-67. USA,Univ., Hawaii Press. 
El-Aidy, F.; A.I. El-Zawily; B.I. El-Sawy and E.M. Hamed (2002). Effect of seaweed extracts on sweet pepper plants grown under protected cultivation. $2^{\text {nd }}$ Inter. Conf. Hort. Sci., 10-12 Sept., 2002, Kafr El-Sheikh, Tanta Univ., Egypt, 28: (3/11): 1000-1012.

El-Kafrawy, A.A. and E.A. Radwan (2008). Effect of different levels of compost on air and soil borne diseases, vegetative growth and yield of cucumber under protected cultivation. J. Agric. Sci. Mansoura Univ., 33 (3): 2165-2176.

El-Lithy, Y.T.; H.M. Yacoup and E.H. Hassan (1992). Effect of planting densities and $\mathrm{N}$ levels on plant growth and yield of squash (Cucurbita pepo L.) Egypt. J. Appl. Sci., 7: 40-53.

El-Mansi, A.A. ; H.M. Arisha and A.I. El-Kassas (2004). Effect of organic manure sources on growth, chemical contents and yield of pea plants under sandy soil conditions. Zagazig J. Agric. Res., 31 (5): 2097-2121.

El-Saei, M. A. and E.A.A. Tartoura (2004). Field evaluation of brown algae and two sources of $\mathrm{N}$-fertilizers on pea plants. International Symposium on Cycling and Utilization of Organic wastes Oct. 8-11. Hangzho, China.

El-Shabrawy, R.A. (1997). The relationship between levels, sources of nitrogen application and some micronutrient treatments on summer squash (Cucurbita pepo L.) Ph.D. Thesis, Fac. Agric. Mansoura Univ., Egypt.

El-Sherif, M.F.A. (2006). Growth and yield of cucumber as influenced by compost and nitrogen fertilizer in sand soil using nuclear technique for determination of nitrogen. Ph. D. Thesis, Fac. Agric. Ain Shams Univ., Cairo, Egypt.

Eris, A.; H. O. Sivritepe, and N. Sivritepa. (1995). The effects of seaweed (Ascophyllum nodosum) extract on yield and quality criteria in peppers. Acta Hort. 412: 185 - 192.

Gomez, K.A. and A.A. Gomez (1984). Statistical procedures for agricultural research. John Wiley and Sons, New York, $2^{\text {nd }}$ ed., 68 p.

Hamail, A.F.; M.M. Abd El-Rahman and S.M. Faried (1994). Effect of sources and rates of nitrogen on vegetable growth and yield of squash (Cucurbita pepo L.). J. Agric. Sci. Mansoura Univ., 19 (2): 787-794.

Hamed, E.M. (1997). Studies on seaweed extracts and shoot pruning on sweet peeper yield under plastic greenhouse. M.Sc. Thesis, Fac. Agric. Tanta Univ., Egypt.

Hellal F. A. (2007). Composting of Rice Straw and its Influences on Iron Availability in Calcareous Soil. Research J. Agric. and Biological Sciences, 3(2): 105-114.

Hossein, H. A. (2008). Effect of various types and rates of organic manures on vegetative growth, pigments and chemical composition of leaves, yield and spear pigments of broccoli. J. Agric. Sci. Mansoura Univ., 33(3): 2045- 2060.

Ibrahim, E.A. and E.M. Selim (2007). Effect of irrigation intervals and nitrogen fertilizer rates on summer squash (Cucurbita pepo L.) growth, yield, nutritional status and water use efficiency. J. Agric. Sci. Mansoura Univ., 32 (12): 10333-10345. 
Jackson, M.L. (1970). Soil Chemical Analysis. Prentic Hall, Englewood Ceiffs, N.J.

Jacobs, M.B. (1951). The chemical analysis prentice. Hall of India Private Limited, New Delhi, pp. 111-204.

Kabeel, S. M. A and N. A. Hasanin (2006). Increasing potato productivity growth in sandy soil through organic and bioferilizer. J. Agric. Sci. Mansoure Unvi., 31 (2): 951-962.

Koller, H. R. (1972). Leaf area leaf weight relation in soybean canopy. Crop Sci., $12: 180-183$.

Kotb, M.I. (1994). Soil and water managements practices for some crops production. Ph. D. Thesis, Soil Sci., Fac. Agric. Moshtohor, Zagazig Univ., Egypt.

Kumaran, S.S.; S. Natarajan and S. Thamburaj (1998). Effect of organic an inorganic fertilizers on growth, yield and quality of tomato. South Indian. Horti., 46 (3-6): 203- 205.

Kusima, P. (1989). The effect of foliar application of seaweed extract on potato. J. Agric. Sci. Finl. , 61(5): 371-377.

Lee, S.B., (2006). Composting of rice straw and hardwood bark with oilseed sesame cake and rice bran. 18 Worled Congress of Soil Science,

Luu Hong Man1, Vu Tien Khang1,Takeshi Watanabe (2001). Improvement of soil fertility by rice straw manure Omonrice 9: 68-73.

Marschner, H. (1995). Mineral nutrition in higher plants. Academic Press, Harcourt Brac Jananovish, Publishers P.674.

Nelson, W.R. and J. Van Staden (1984). The effect of seaweed concentrate on growth of nutrient stressed, greenhouse cucumbers. Hort. Sci., 19 (1): 81-82.

Nour E.M.E. (2004). Physiological studies on pea crop under sandy soil conditions. Ph. D. Thesis, Fac. Agric. Zagazig Univ., Egypt.

Olsen, S.R. and L. E. Sommers (1982). Phosphorus. In: Page, A. L., R. H. Miller, and D. R. Keeney (Eds.) Methods of Soil Analysis. Part2, Amer. Soc. Agron., Madison, W. I., USA., pp. $403-430$.

Page, A.L.; R.H. Miller and Keeney, D. R. (1982). "Methods of Soil Analysis". Part II- Chemical and microbiological properties. A. S. A. Madison Wisc., USA.

Piper, C.S. (1947). "Soil and Plant Analysis". The Univ. of Adelaide, Adelaide.

Rashid, M.; T. Horiuchi and S. Oba, (2001). Enrichment of rice straw compost by adding cow dung and soybean plants and its effects on wheat yield ans soil nutrients. Jpn. J. Crop Sci., 70(2): 55-56.

Rechcigl, J.E. (1995). Soil amendments and environmental quality. Lewis Publishers CRC. New York. PP. 489.

Richards, L.A. (1954). "The diagnosis and Improvement of Saline and Alkali Soils". USDA, Handbook, 60.

Saleh, M. M. ; F. M. Darwish and M. M. Hana (2007). Effect of different types and levels of organic fertilizer combined with bio-fertilizer on growth and yield of tomato grown in sandy soil. J. Agric. Sci. Mansura Univ., 32 (7): 5553- 5568.

Seyedbagheri, M.M. (1999). Evaluation of compost in organic potato presented at state organic grower's. Annual Meeting Mountain Home. 
Shaheen, A.M. ; F.A. Rizk and Z.F. Fawzy (2007). Yield and some chemical constituents of onion as influenced by organic manures. J. Agric. Sci. Mansoura Univ., 32 (10): 8513-8523.

Shehata, S.M. (2001). Effect of some organic wastes application on growth, chemical contents and yield of squash plant. J. Agric. Sci. Mansoura Univ., 26 (9): 5695-5704.

Singh, J.P. (1988). A rapid method for determination of nitrate in soil and plant extracts. Plant and Soil, 110: 137-139.

Snedecor, W. G. and G. W. Cochran (1967). "Statistical Method" Lowa State Univ., Press, Amer, USA. $6^{\text {th }}$ Ed. pp. 393.

Tartoura , E.A.A. and M. A. El-Saei (2005). Can brown algae and yeast extracts improve potatoes yield?. J. Environ. Sci., 30: 55-81.

Tartoura, E. A. A. and M. A. El-Saei (2007). How far seaweed can include in the organic farming programs ?. J. Agric. Sci. Mansoura Univ., 31 (7) 4813-4823.

Turemis, N.F. ; S. Kafkas and N. Conickeiogla (1998). Effect of fertilizer produced from the seaweed (Ascophyllum nodosum) on strawberry yield and quality. Hort. Abst., 68 (12): 1376.

Van Staden, J.; S.J. Upfold and F.E. Drewes (1994). Effect of seaweed concentrate on growth and development of the marigold (Tagetes patula). J. Appl. Phys., 6: 427-428.

Ye, J.W.; Y.M. Lu; Z.K. Zhou; J.W. Ye; Y.M. Lu and Z.K. Zhou (1999). Study on the effect of applying organic humus manure on the production and fruit quality of pummelo cultivar Guanxi Miyou. South China Fruits, 28: 20-22.

Zhang, X. ; E.H. Eruin and R.E. Schmidt (2003). Physiological effects of liquid application of a seaweed and humic acid on creeping bent grass. J. Amer. Soc. Hort. Sci., 128 (4): 492-496.

Zodape, A. (2002). Seaweed as a biofertilizer. J. Sci. Ind. Res., 60 (5): 378382.

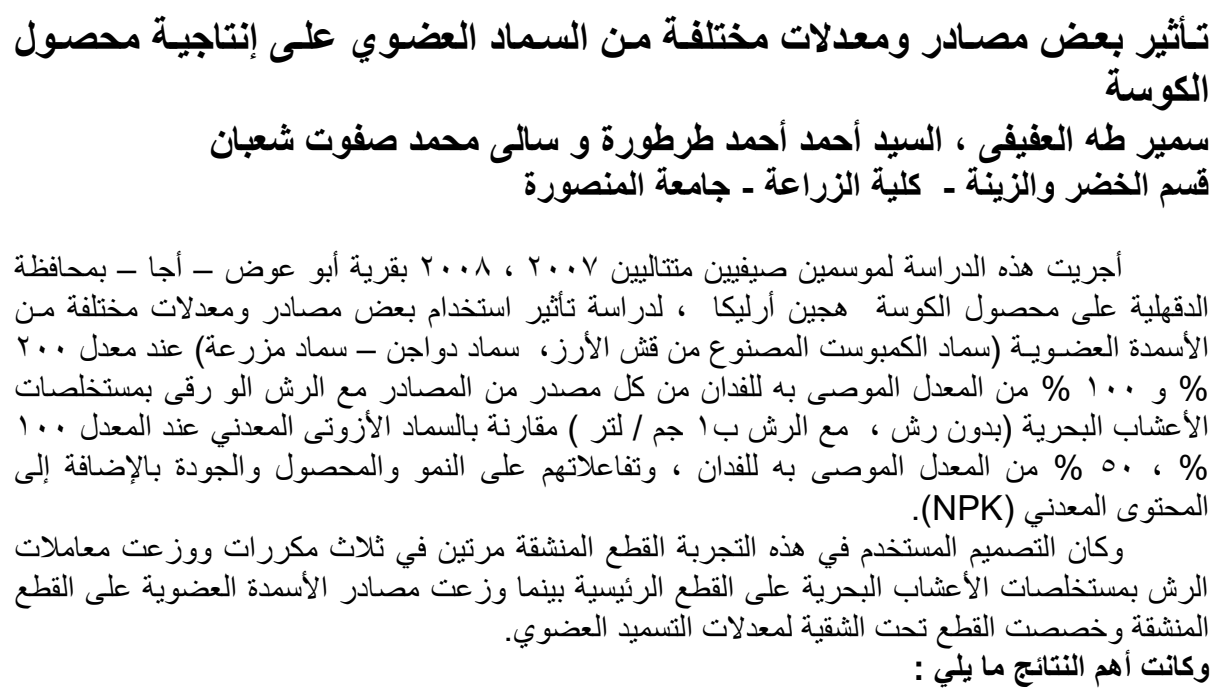




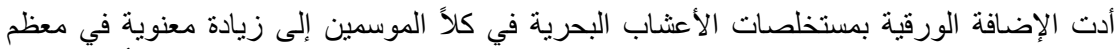

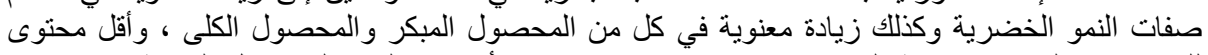

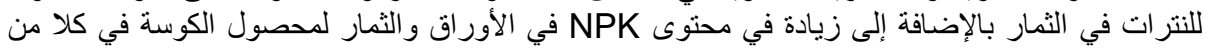

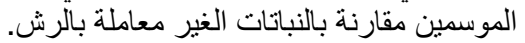

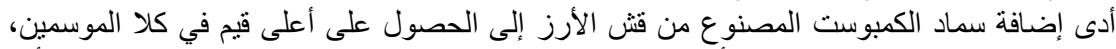

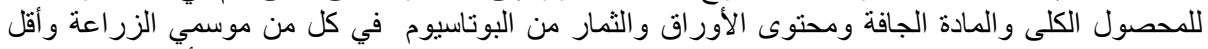

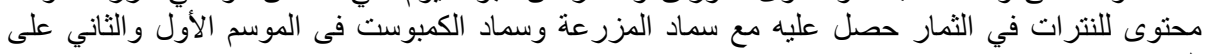

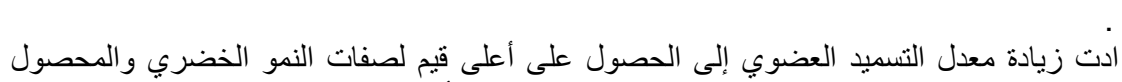

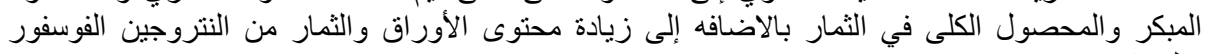

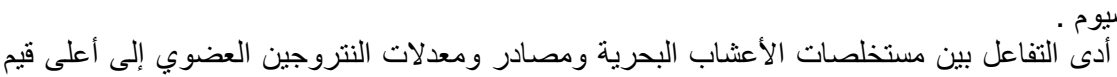
و البوناسيوم .

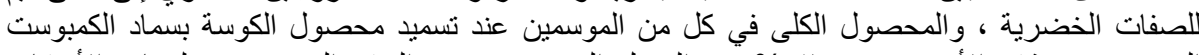

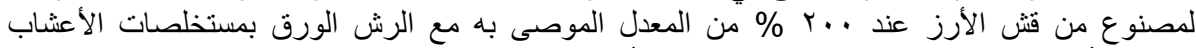

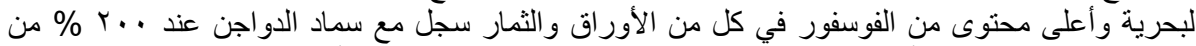

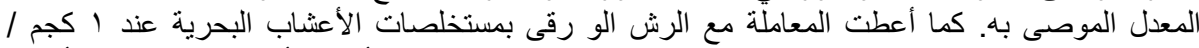

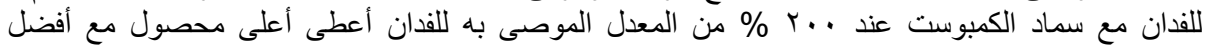

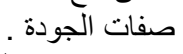

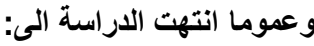

• بإجر اء التقييم الأقتصادى اتضح التح أن الرش بمستخلصات الأعشاب البحرية مع إضافة سماد المزرعة يليه

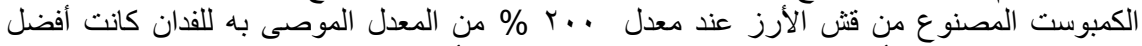

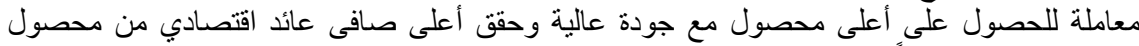

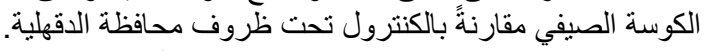

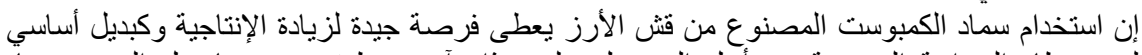

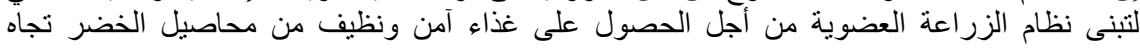
الزراعة التقليدية مع تقليل التلوث البنة البيئي. علاوة على أن إضافة الأسمدة العضوية يؤدى إلى تحسين خواص التربة الطبيعية والكيماوية وزيادة خصوبة التربة. 